\title{
Market Disruption, Export Market Disruption, Compensation and GATT Reform*
}

\author{
JAGDISH N. BHAGWATI \\ Massachusetts Institute of Technology
}

\begin{abstract}
Summary. - This paper analyzes the problem of market disruption as it currently afflicts the exporting countries, chiefly LDCs. Based on the analysis of optimal policy intervention under endogenous uncertainty, developed by Bhagwati and Srinivasan (Journal of International Economics, November 1976), it develops a complete set of rules by which the developed and less developed countries may abide, under a revised GATT code, when faced by the problem of increased competitiveness of LDC exports to DC markets. These rules include the compensation of LDCs by DCs, in varying degrees, for both potential and actual exercise of import restrictions by $\mathrm{DCs}$
\end{abstract}

\section{INTRODUCTION}

This paper addresses itself to the issue of 'market disruption' and suggests schemes for compensating the less developed countries (LDCs) who face (what may aptly be described as) 'export market disruption' when the importing, developed countries (DCs) invoke protective devices, such as 'voluntary' export restraints, to assist domestic industries seeking relief from foreign competition.

Section I deals with the problem of defining market disruption. Section II considers the GATT Article XIX on the subject and its relationship to national legislations. In light of this, Section III considers the principal forms in which market-disruption-related restrictions have been invoked, focusing then on 'voluntary' export restraints (VERs) and the more sustained and formal multilateral arrangements (i.e. the LTA which restricts the exports of textiles). Section IV then discusses the welfareimpact of the possibility of market-disruptioninduced restrictions which LDCs face on their exports of manufactures. Section $V$ then assesses the need for compensation that the welfare losses to LDCs imply from this analysis and, in light of this, develops specific proposals for such compensation. Section VI suggests ways in which the GATT Article XIX could be modified to implement these suggestions.
Appendix I contains a brief review of one precedent, where the 'importing' country provided compensation to the 'exporting' country for 'export market disruption', so to speak. This is the case of the United States compensating Turkey for adjustment assistance to Turkish poppy farmers (the objective being to enable the farmers to shift to non-poppy farming at no loss). Appendix II, on the other hand, is a theoretical exercise, in a generalequilibrium framework, of the phenomena of export market disruption and provides the necessary analytical support to the compensation schemes discussed in the text of the paper.

* This paper was originally commissioned by UNCTAD, Geneva, Switzerland, but does not represent or reflect the UNCTAD Secretariat's views. Thanks are due to Michael Pelcovits and Paul Krugman for excellent research assistance and to $T$. $N$. Srinivasan for co-authoring Appendix II, with partial financial support from the National Science Foundation Grant No. SOC 74-13210. Helpful comments on an earlier draft were received from Robert Baldwin, Fred Bergsten, Charles Blitzer, Peter Diamond, Murray Kemp, Hendrik Houthakker, R. Krishnamurti, C. P. Kindleberger, Gerry Helleiner, Jan Tumlir, Stanley Metzger, John Williamson, Bela Balassa, Wolfgang Mayer and Koichi Hamada. 


\section{THE CONCEPT OF MARKET DISRUPTION}

In a basic sense, market disruption is an old, protectionist concept: imports are considered disruptive of the domestic industry in the domestic market and hence must be curtailed and regulated. In this sense, virtually all imports are market-disrupting and indeed if one examines, in a 'revealed preference' fashion, the demands for protection by many industries in almost all countries, this loose and allembracing version is, in fact, what would most nearly reflect the intent of the spokesmen for these industries.

However, in an international economy which, in the post-war, post-GATT world has been geared to increasing trade liberalization, the institutions which have governed the use of protective devices for manufactures have taken a narrower view of market disruption.

This is particularly true of the GATT, where Article XIX is designed to handle cases of 'serious injury' to domestic industries and is set within the context of other rules designed to constrain the use of protection by member countries. $^{1}$

It is correspondingly true also of national legislations which were enacted to correspond to Article XIX and related GATT provisions. Thus the US had established corresponding 'escape clause' procedures by Executive Order 9832 from 1947 to 1951 , by Section 7 of the 1951 Trade Agreements Extension Act between 1951 to 1962 , and by Section 301 of the Trade Expansion Act from $1962 .^{2}$

Under these legislations, for example, the successful invoking of protection required the public demonstration of injury, caused by tariff-concession-led imports, to the US Tariff Commission which would, in turn, convey its finding to the President who, in turn, could act on it, consistently with the national legislation and the GATT rules.

On the other hand, as we shall discuss presently in greater detail, the national executive has often been willing to sidetrack GATT restrictions and associated national processes for seeking relief under market disruption and to invoke measures, outside of the GATT framework, to regulate the flow of such imports. The most potent such measure has been the VERs which have tended to proliferate since the 1950 s.

In consequence, it would be appropriate to say that, if we were to rank the different groups and institutions, seeking to define market disruption and to obtain relief from imports therewith, according to the degree of restrictiveness that they would apply to the concept, the ranking would be as follows:

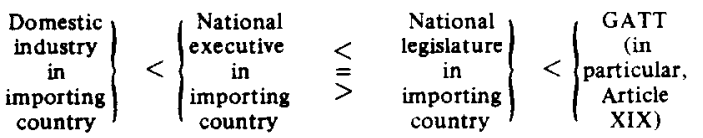

That is to say, the domestic industry, seeking relief from imports, would apply the least restrictive criteria to define market disruption; and the highest, in restrictiveness, would be the GATT, which seeks generally to minimize interferences with expanding trade. In between are the national executives and legislatures whose relative actions and attitudes on the issue of market disruption are likely to vary. Thus, in the United States, the executive has been, via VERs, de facto less restrictive in the interpretation of market disruption, whereas the legislative statutes have been closer to GATT, as noted above. On the other hand, this is quite consistent with the legislative representatives, interested in specific industries in their constituencies, being the effective moving force in getting a free-trade-oriented executive to enact the VERs. Hence one must distinguish between executive actions and legislation, on the one hand, and the executive and legislative bodies' attitudes towards the issue of market disruption, on the other hand. ${ }^{3}$

In light of the foregoing, it is clear that the loosest, industry-based view of market disruption would extend to all competition with imports in the domestic market and indeed no evidence of any serious injury would need to be established. Thus, as Metzger has noted, the provisions of HR 18970 , the socalled US Trade Act of 1970, if it had become law, would have effectively elevated this view of market disruption to the status of the operating criterion for invoking protection (thus going beyond what GATT Article XIX envisaged). ${ }^{4}$ The escape clause would have retained a Tariff Commission investigation but reduced the definition of injury to one where the domestic industry's relative share in the domestic market had fallen, while also removing Presidential discretion in vetoing Tariff Commission recommendations for escape clause action. ${ }^{5}$

By contrast, Article XIX of GATT, as seen in Section II, restricts the "emergency action on imports of particular products' to situations which satisfy three conditions: (i) that the alleged disruption should have been the result of the obligations incurred by a contracting party under this Agreement, including tariff concessions; (ii) that the product must be 
imported in 'increased quantities'; and (iii) that conditions must exist which 'cause or threaten serious injury to domestic producers'. While these conditions, and shifts in their interpretation over time, are discussed in the next section, it is pertinent to note immediately that the GATT envisions a much narrower interpretation of market disruption and hence a correspondingly smaller scope for invoking legitimate interferences with imports.

In keeping with this view of the matter, the associated national legislation has been relatively strict in interpreting market disruption as well. Thus, in the United States, the invoking of the escape clause has had to involve a public inquiry by the US Tariff Commission which had to apply legislated criteria, similar to those of Article XIX, to the case at hand: the US industries going the escape clause route have had to argue that concessioninduced imports were causing serious injury, and have often failed to win their case.

The invoking of protective devices by industries seeking curtailment of imports despite the GATT Article XIX and corresponding national legislations has therefore taken the route of executive action, typically in the form of VERs, outside of this framework; hence, the de facto definition of market disruption has turned out to be substantially closer to the importing industry's viewpoint than the GATT rules might suggest.

A review of the existing VERs, including the LTA governing the trade in textiles, reveals that the concept of market disruption that can successfully be invoked to get political, executive action in DCs tends to include the following 'weakly restrictive' features:

(i) There need not be a sharp rise in imports; it is enough for the relative share of foreign imports to increase sharply in the domestic market.

(ii) It is usually helpful to appeal to the notion that foreign competition is from lowpriced' imports. The Europeans have the term 'abnormal competition' to refer to this phenomenon and claim market disruption when, according to J. De Bandt, the import price is below the domestic price by 'the portion of value added which they are unwilling to forego'. This is a strange notion indeed for economists to contemplate: after all, trade will reflect comparative advantage and imports will be effected when they are cheaper than domestic output. But it is a notion that is widely held and presumably is occasionally successful in getting protection.

The reliance on criteria such as decline in domestic industry's share in the domestic market and the need to compete with 'lowpriced' imports have thus replaced the need to show that there is 'serious injury' in any other sense (e.g. that unemployment is rapidly resulting in the industry) and that it is attributable to increasing imports.

Hence the matter has become of serious concern to LDCs whose ('low-priced', 'lowcost') exports have now come fairly significantly to face the prospect of marketdisruption-induced restrictions and, indeed, are in some important cases (such as the LTA) already under such restraints. ${ }^{7}$ Therefore, prior to discussing the manner in which such prospects can be regulated and compensated for, it is necessary to examine in greater depth the history and present status of GATT rules on the subject, proceeding then to a fuller exploration of the growth of VERs and other restrictions outside of the GATT-and-related framework.

\section{GATT RULES AND NATIONAL LEGISLATIONS}

It is useful to put the current GATT rules on the phenomenon of 'serious injury', as applicable to market disruption, in historical perspective as also in relation to the rest of GATT articles.

It is fair to say that GATT has had built into its basic structure an asymmetry under which agriculture has managed to be relatively easy to protect but interferences with trade in manufactures have been made more difficult. Thus, for example, the GATT Article XI is explicit in ruling out quotas as follows:

1. No prohibitions or restrictions other than duties, taxes or other charges, whether made effective through quotas, import or export licences or other measures, shall be instituted or maintained by any contracting party on the importation of any product of the territory of any other contracting party or on the exportation or sale for export of any product destined for the territory of any other contracting party.

2. The provisions of paragraph 1 of this Article shall not extend to the following:

(a) Export prohibitions or restrictions temporarily applied to prevent or relieve critical shortages of foodstuffs or other products essential to the exporting contracting party;

(b) Import and export prohibitions or restrictions necessary to the application of standards or regulations for the classification, grading or marketing of commodities in international trade; 
(c) Import restrictions on any agricultural or fisheries product, imported in any form, necessary to the enforcement of governmental measures which operate:

(i) to restrict the quantities of the like domestic product permitted to be marketed or produced, or, if there is no substantial domestic production of the like product, of a domestic product for which the imported product can be directed substituted; or

(ii) to remove a temporary surplus of the like domestic product, or, if there is no substantial domestic production of the like product, of a domestic product for which the imported product can be directly substituted, by making the surplus available to certain groups of domestic consumers free of charge or at prices below the current market level; or

(iii) to restrict the quantities permitted to be produced of any animal product the production of which is directly dependent, wholly or mainly, on the imported commodity, if the domestic production of that commodity is relatively negligible.

It is clear from the above that the essential exemptions contemplated under Article XI.2 relate to agricultural commodities (with domestic price-support programmes, etc.) and do not help manufacturing industries that desire protection.

The basic protective outlet for manufactures (as distinct from Articles such as XII relating to balance of payments and XXI concerning security exceptions) which seek protection from imports on alleged grounds of 'market disruption' is provided under Article XIX whose full text states:

1. (a) If, as a result of unforeseen developments and of the effect of the obligations incurred by a contracting party under this Agreement, including tariff concessions, any product is being imported into the territory of that contracting party in such increased quantitics and under such conditions as to cause or threaten serious injury to domestic producers in that territory of like or directly competitive products, the contracting party shall be free, in respect of such product, and to the extent and for such time as may be necessary to prevent or remedy such injury, to suspend the obligation in whole or in part or to withdraw or modify the concession.

(b) If any product, which is the subject of a concession with respect to a preference, is being imported into the territory of a contracting party in the circumstances set forth in sub-paragraph $(a)$ of this paragraph, so as to cause or threaten serious injury to domestic producers of like or directly competitive products in the territory of a contracting party which receives or received such preference, the importing contracting party shall be free, if that other contracting party so requests, to suspend the relevant obligation in whole or in part or to withdraw or modify the concession in respect of the product, to the extent and for such time as may be necessary to prevent or remedy such injury.

2. Before any contracting party shall take action pursuant to the provisions of paragraph 1 of this Article, it shall give notice in writing to the CONTRACTING PARTIES as far in advance as may be practicable and shall afford the CONTRACTING PARTIES and those contracting parties having a substantial interest as exporters of the product concerned an opportunity to consult with it in respect of the proposed action. When such notice is given in relation to a concession with respect to a preference, the notice shall name the contracting party which has requested the action. In critical circumstances, where delay would cause damage which it would be difficult to repair, action under paragraph 1 of this Article may be taken provisionally without prior consultation, on the condition that consultation shall be effected immediately after taking such action.

3. (a) If agreement among the interested contracting parties with respect to the action is not reached, the contracting party which proposes to take or continue the action shall, nevertheless, be free to do so, and if such action is taken or continued, the affected contracting parties shall then be free, not later than ninety days after such action is taken, to suspend, upon the expiration of thirty days from the day on which written notice of such suspension is received by the CONTRACTING PARTIES, the application to the trade of the contracting party taking such action, or, in the case envisaged in paragraph $1(b)$ of this Article, to the trade of the contracting party requesting such action, of such substantially equivalent concessions or other obligations under this Agreement the suspension of which the CONTRACTING PARTIES do not disapprove.

(b) Notwithstanding the provisions of subparagraph $(a)$ of this paragraph, where action is taken under paragraph 2 of this Article without prior consultation and causes or threatens serious injury in the territory of a contracting party to the domestic producers of products affected by the action, that contracting party shall, where delay would cause damage difficult to repair, be free to suspend, upon the taking of the action and throughout the period of consultation, such concessions or other obligations as may be necessary to prevent or remedy the injury.

The GATT view of the invoking of escape clause' protection in the matter of market disruption, as implicit in Article XIX, was therefore traditionally a rather strict one. However, its interpretation has been somewhat less strict than the language would suggest.

Thus, the 'unforeseen developments' in 
paragraph $1(a)$ have been interpreted as inclusive of situations deriving from the fulfilment by a member of its obligations (under Articles III or IX). ${ }^{8}$ More important, the interpretation of the phrase increased quantities' in paragraph $k$ has been formally agreed to as including the case where imports may have increased only relatively to domestic production (as, in fact, was explicit in the corresponding Havana Charter, Article 40 text). ${ }^{9}$ Finally, the Article clearly states that the relaxation of commitments under it will be 'for such time as may be necessary': this, in turn, has been clarified to imply that while the expectation is one of short-term, temporary invoking of protection, the phrasing does allow for longer and continuous invoking of Article $\mathrm{XIX}^{10}$

But, subject to these liberal interpretations, the scope of Article XIX is essentially narrow. Basically, it does require that concession-led increasing imports be a cause of serious injury. It also builds into the mechanism the possibility of compensation to the exporting member countries that thereby lose the tariff concessions that are to be suspended: reflecting, of course, the fact that Article XIX explicitly pertains to imports of articles on which a concession had earlier been granted and which is being suspended by the invoking of Article $\mathrm{XIX}{ }^{11}$

Of these two restrictive aspects of Article $\mathrm{XIX}$, it is the former that has caused the critical difficulty for industries seeking relief from imports, by claiming market disruption, under national legislations. Thus, in the United States (until the 1974 legislation), for example, the escape clause actions (under the US legislations, noted in Section I) have been remarkably unsuccessful, as is evident from Table 1. Thus, of 134 investigations instituted by the Commission until 1962, the process terminated in Presidential invocation of the escape clause in only 15 cases, with yet more dramatic failure rates for the post-1962 period!

The result has been a rather limited resort to GATT Article XIX for relief by industries alleging market disruption; national legislations and processes, reflecting the tougher criteria of Article XIX, have eliminated the bulk of the protectionist demands under the broad umbrella of 'market disruption'. The corresponding paucity of actions under Article XIX is therefore only natural and can be inferred from Table 2 which lists by country, the invoking (in terms of both frequency and commodity composition) of Article XIX until 1970.

It may also be noted that the invoking of
Article XIX has generally taken the form of an increase in bound tariffs and, to a lesser degree (in about a third of the cases), of the imposition of QRs. ${ }^{12}$ Furthermore, it has been estimated that the developing countries' exports were involved in more than half of the developed countries' invoking of Article XIX. The restrictions imposed in these cases were removed within a year in a third of the cases involving developing countries whereas in half the total number of cases, the measures had been in force for over five years.

\section{GROWTH AND EXISTENCE OF PRINCIPAL FORMS OF MARKET- DISRUPTION-RELATED INSTRUMENTS OF PROTECTION}

Basically, therefore, national governments in DCs responding to the protectionist pressures from their industries, have responded in two principal ways: (1) by trying to weaken the restrictive nature of GATT rules on market disruption; and (2) by bypassing the GATT framework altogether.

Of these, the former has been the less important and has, in fact, not resulted in any major changes at the GATT to date. Apparently the first public reference to 'market disruption' specifically appears to have been made by the United States, via Mr. Douglas Dillon in Tokyo at the 15th GATT session in $1959 .{ }^{13}$ This was to lead to the appointment of a GATT working party in June 1960, to examine the issue of market disruption. Their initial efforts amounted to defining market disruption to include four elements 'in combination': ${ }^{14}$

(i) a sharp and substantial increase or potential increase of imports of particular products from particular sources;

(ii) these products are offered at prices which are substantially below those prevailing for similar goods of comparable quality in the market of the importing country;

(iii) there is serious damage to domestic producers or threat thereof;

(iv) the price differentials referred to in paragraph (ii) above do not arise from governmental intervention in the fixing or formation of prices or from dumping practices.

The Working Party advocated a multilateral and 'constructive' approach towards this problem, which would permit trade expansion. Its recommendation that there be a permanent Committee on Market Disruption was accepted and this Committee, in collaboration with the International Labour Office, was to consider 
Table 1. Escape-clause actions in the United States, $1947-1962,1963-1969$ and $1970-1973$

(A) Outcome or current status of escape-clause investigations initiated by the United States Tarriff Commission as of 1 July 19621

Investigations instituted by the commission

Investigations dismissed by the commission at applicant's request

Knit gloves and mittens, wool (6-0) (11 July 1951)

Hard-fibre cords and twines (4-0) (14Jan. 1953)

Fluorspar (1st investigation) (6-0) (23 Nov. 1953)

Wood screws (4th investigation) (4-0) (9 Apr. 1956)

Cotton blouses (5-0) (22 June 1956)

Certain cotton cloth (gingham) (5-0) (29 Jan. 1957)

Creeping red fescue seed (6-0) (1 June 1961)

Umbrella frames (2nd investigation) (3-0) (21 Sept. 1961)

Umbrellas (3-0) (21 Sept. 1961)

Investigations terminated by the commission without formal findings

Straight pins (1st investigation) (6-0) (22 June 1954)

Safety pins (1st investigation) (6-0) (22 June 1954)

Leather handbags (6-0) (14 Mar. 1956)

Toyo cloth caps (4-0) (21 June 1957)

Fine-mesh wire cloth (3-2) (14 July 1958)

Nails, spikes, tacks, brads and staples (6-0) (12 Mar. 1959)

Galvanized fencing wire and galvanized wire fencing (6-0) (12 Mar. 1959)

Broadwoven silk fabrics (5-0) (26 June 1959)

Tennis rackets (4-2) (19 Apr. 1961)

Investigations in which decisions by the commission are pending

Vanilion

Household china tableware and kitchenware

Earthenware table and kitchen articles

Hatters' fur (3rd investigation)

Investigations completed by the commission

Investigations in which the commission dismissed the applications after preliminary inquiry under procedure provided for in Executive orders (no repor ts issued)

Marrons (4-0) (27 Aug. 1948)

Whiskies and spirits (5-0) (3 Jan. 1949)

Crude petroleum and petroleum products (4-2) (3 May 1949)

Hops (4-2) (11 May 1949)

Knitted berets (1st investigation) (3-3) (8 July 1949)

Sponges (3-3) (22 July 1949)

Narcissus bulbs (6-0) (13 Jan. 1950)

Knitted berets (2nd investigation) (5-1) (13 Jan. 1950)

Reeds (5-0) (17 Feb. 1950)

Beef and veal (3-3) (30 June 1950)

Silk woven fabrics (5-0) (21 Sept. 1950)

Aluminum and alloys (6-0) (21 Nov. 1950)

Lead (5-0) (25 Jan. 1951)

Stencil silk, dyed or colored (6-0) (7 June 1951)

Investigations in which the commission decided against escape action (no reports sent to the President)

Spring clothespins (1st investigation) (5-1) (20 Dec. 1949)

Wood screws (1st investigation) (4-2) (29 Dec. 1951)

Blue-mould cheese (5-1) (12 June 1952)

Motorcycles and parts (4-2) (16 June 1952)

Spring clothespins (2nd investigation) (3-2) (21 Aug. 1952)

Goundfish fillets (1st investigation).(3-2) (4 Sept. 1952)

Bicycles and parts (1st investigation) (5-0) (9 Oct. 1952)

Glace cherries (3-2) (17 Oct. 1952)

Bonito and tuna, not in oil (3-2) (26 Nov. 1952)

Household china tableware (4-0) (5 Feb. 1953) 
Wood screws (2nd investigation) (3-1) (27 Mar. 1953)

Pregnant mares' urine (4-0) (2 Apr. 1953)

Chalk whiting (3-1) (9 Apr. 1953)

Woodwind musical instruments (5-0) (28 Apr. 1953)

Cotton-carding machinery (5-0) (29 July 1953)

Metal watch bracelets and parts (6-0) (20 Aug. 1953)

Rosaries (6-0) (21 Aug. 1953)

Mustard seeds $(6-0)$ (10 Dec. 1953)

Ground chicory (5-0) (7 Sept. 1954)

Coconuts $(6-0)(25$ Oct. 1954)

Wool gloves and mittens (5-1) (28 Dec. 1954)

Hardwood plywood (1st investigation) (5-0) (2 June 1955)

Red fescue seed (1st investigation) (4-0) (22 June 1955)

Dressed rabbit furs (6-0) (29 Feb. 1956)

Cotton pillowcases (3-2) (21 Nov. 1956)

Certain jute fabrics (5-0) (15 May 1957)

Bicycles (3 rd investigation) (6-0) (19 Aug. 1957)

Wool feldt, non-woven (5-0) (6 Jan. 1958)

Garlic (2nd investigation) (5-0) (19 Feb. 1958)

Barium chloride $(6-0)$ (10 Oct. 1958)

Certain carpets and rugs (1st investigation) (3-2) (12 Jan. 1959)

Scissors and shears (2nd investigation) (6-0) (25 Feb. 1959)

Handmade glassware (2nd investigation) (6-0) (21 May 1959)

Axes and axe heads (5-0) (21 May 1959)

Calf and kip leather (5-0) (21 May 1959)

Hardwood plywood (2nd investigation) (4-2) (22 June 1959)

Mink skins (6-0) (17 Sept. 1959)

Red fescue seed (2nd investigation) (5-0) (28 Oct. 1959)

Zinc sheet (3-2) (14 Jan. 1960)

Women's and children's leather gloves (5-0) (21 Mar. 1960)

Typewriters (6-0) (10 May 1960)

Lamb, mutton, sheep and lambs (4-2) (1 June 1960)

Barbed wire (4-0) (3 Aug. 1960)

Cast-iron soil-pipe fittings (6-0) (23 Aug. 1960)

Crude horseradish (6-0) (15 Sept. 1960)

Hatters' fur (2nd investigation) (6-0) (7 Oct. 1960)

Iron ore (5-0) (30 Dec. 1960)

Ultramarine blue (6-0) (16 Mar. 1961)

Plastic raincoats (4-2) (29 Mar. 1961)

Cantaloups (6-0) (30 Mar. 1961)

Cellulose filaments (ray on staple fibre) (4-2) (10 Apr. 1961)

Watermelons (6-0) (20 Apr. 1961)

Rolled glass $(3-2-1)^{2}$ (25 May 1961)

Procaine and salts and compounds thereof (3-0) (2 Nov. 1961)

Standard clothespins (5-0) (14 Feb. 1962)

Creeping red fescue seed (2nd investigation) (3-2) (21 May 1962)

Investigations in which the vote of the commission was evenly divided (reports sent to the President)

Handmade blown glassware (1st investigation) (3-3) (22 Sept. 1953)

Spring clothespins (3rd investigation) (3-3) (6 Oct. 1954)

Wood screws (3rd investigation) (3-3) (27 Oct. 1954)

Fluorspar (2nd investigation) (3-3) (18 Jan. 1956)

Para-aminosalicyclic acid (3-3) (14 June 1956)

Binding twines (2-2) (9 Dec. 1960)

Hard-fibre cords and twines (2nd investigation) (2-2) (9 Dec. 1960)

Alsike clover seed (2nd investigation) (2-2) (7 Aug. 1961)

Investigations in which the commission decided in favour of escape action (reports sent to the President)

Women's fur felt hats and hat bodies (5-0) (25 Sept. 1950)

Hatters' fur (1st investigation) (6-0) (9 Nov. 1951)

Garlic (1st investigation) (4-2) (6 June 1952)

Watches (1st investigation) (4-2) (14 June 1952)

Dried figs (5-0) (24 July 1952)

Tobacco pipes and bowls (4-0) (22 Dec. 1952) 
Screen-printed silk scarves (4-0) (13 Apr. 1953)

Scissors and shears (1st investigation) (4-2) (12 Mar. 1954)

Groundfish fillets (2nd investigation (3-2) (7 May 1954)

Lead and zinc (1st investigation) (6-0) (21 May 1954)

Alsike clover seed (1st investigation) (6-0) (21 May 1954)

Watches (2nd investigation) (4-2) (28 May 1954)

Bicycles (2nd investigation) (4-1) (14 Mar. 1955)

Ferrocerium (lighter flints) (6-0) (21 Dec. 1955)

Toweling of flax, hemp, or ramie (6-0) (15 May 1956)

Groundfish fillets (3rd investigation) (6-0) (12 Oct. 1956)

Velveteen fabrics (6-0) (24 Oct. 1956)

Violins and violas (3-2) (29 Jan. 1957)

Straight pins (2nd investigation) (4-2) (30 Jan. 1957)

Safety pins (2nd investigation) (4-2) (30 Jan. 1957)

Spring clothespins (4th investigation) (4-1) (10 Sept. 1957)

Stainless steel table flatware $(6-0)(10$ Jan. 1958)

Umbrella frames (1st investigation) (3-2) (14 Jan. 1958)

Clinical thermometers (3-2) (21 Feb. 1958)

Lead and zinc (2nd investigation) (6-0) (24 Apr. 1958)

Tartaric acid (5-0) (14 Jan. 1959)

Cream of tartar (3-2) (14 Jan. 1959)

Cotton typewriter-ribbon cloth (4-0) (30 June 1960)

Baseball and softball gloves (6-0) (1 May 1961)

Ceramic mosaic tile (6-0) (10 May 1961)

Sheet glass (6-0) (17 May 1961)

Certain carpets and rugs (2nd investigation) (4-0) (3 Aug. 1961)

Straight pins (3rd investigation) (4-2) (28 Feb. 1962)

Action by the President on recommendations of the commission in favour of escape action

President invoked the escape clause

Women's fur felt hats and hat bodies (30 Oct. 1950)

Hatters' fur (5 Jan. 1952)

Dried figs (16 Aug. 1952)

Alsike clover seed (1st investigation) (30 June 1954 )

Watches (2nd investigation) (27 July 1954)

Bicycles (2nd investigation) (18 Aug. 1955)

Toweling, of flax, hemp, or ramie (25 June 1956)

Spring clothespins (4th investigation) (9 Nov. 1957)

Safety pins (2nd investigation) (29 Nov. 1957)

Clinical thermometers (21 Apr. 1958)

Lead and zinc (2nd investigation) (22 Sept. 1958)

Stainless steel table flatware (20 Oct. 1959)

Cotton typewriter-ribbon cloth (23 Aug. 1960)

Sheet glass (19 Mar. 1962)

Certain carpets and rugs (2nd investigation) (19 Mar. 1962)

President declined to invoke the escape clause

Garlic (1st investigation) (21 July 1952)

Watches (1st investigation) (14 Aug. 1952)

Tobacco pipes and bowls (10 Nov. 1953)

Scissors and shears (1st investigation) (11 May 1954)

Groundfish fillets (2nd investigation) (2 July 1954)

Lead and zinc (1st investigation) (20 Nov. 1954)

Handmade blown glassware (1st investigation) (9 Sept. 1954)

Spring clothespins ( 3 rd investigation) (20 Nov. 1954)

Screen-printed silk scarves (23 Dec. 1954)

Wood screws (3rd investigation) (23 Dec. 1954)

Fluorspar (2nd investigation) (20 Mar. 1956)

Para-aminosalicylic acid (10 Aug. 1956)

Ferrocerium (lighter flints) (13 Nov. 1956)

Groundfish fillets (3rd investigation) (10 Dec. 1956)

Velveteen fabrics ( 22 Jan. 1957)

Straight pins (2nd investigation) (29 Mar. 1957)

Violins and violas (30 Mar. 1957) 
Umbrella frames (1st investigation) (30 Sept. 1958)

Tartaric acid (14 Mar. 1959)

Cream of tartar (14 Mar. 1959)

Binding twines (7 Feb. 1961)

Hard-fibre cords and twines (2nd investigation) (7 Feb. 1961)

Alsike clover seed (2nd investigation) (1 Oct. 1961)

Baseball and softball gloves (19 Mar. 1962)

Ceramic mosaic tile (19 Mar. 1962)

Straight pins (3rd investigation) (28 Apr. 1962)

\section{(B) Escape-clause actions, 1963-1969}

There were 25 applications for escape-clause relief during 1963-1969, all of which were rejected.

(C) Escape-clause actions, 1970-1973

\begin{tabular}{clcc} 
Year & Industry & Tariff Commission ruling & Presidential action \\
\hline 1970 & Canned sardines & No relief justified & None \\
& Pianos & Yes & Delay in tariff reduction \\
& Flat glass & Tie vote & Delay in tariff reduction \\
& Barbers' chairs & Tie vote & None \\
1971 & Umbrellas & No & None \\
& Non-rubber footwear & Tie vote & $?$ \\
& Billiard and pool balls & No & None \\
1972 & Marble and travertine & Tie vote & None \\
& products & No & None \\
& TV receivers & Yes & None \\
& Earthenware & No & None \\
& Fine china & Tie vote & None \\
& Sheet glass & No & None \\
& Other flat glass & No & None \\
& Electron microscopes & Tie vote & None \\
\hline \multirow{4}{*}{1973} & Brass wind instruments & . &
\end{tabular}

Source: United States Tariff Commission; in William Kelly (1963), especially the paper by Leddy and Norwood, Chapter 3.

Notes:

1. The vote of the commission (where applicable) and the date of the particular action are shown in parentheses.

2. Three commissioners found no injury; two commissioners found injury; one commissioner found a threat of injury.

the economic, social and commercial aspects of market disruption and report on it. ${ }^{15}$ As it happened, this Report never materialized and, in fact, the most important market disruption type restriction that soon materialized, the LTA (Long-Term Arrangement Regarding International Trade in Cotton Textiles), was to be negotiated in 1962 quite without regard to this Committee! In the years that have elapsed since then, the GATT has not managed to regulate market disruption any more than the DCs have managed to alter the basic GATT framework to accommodate less restrictive criteria for invoking market-disruption-related protection.
The fact is that the alternative route of bypassing the GATT altogether to successfully seek restraints on trade in cases of market disruption defined far more weakly than in GATT, is the one that has been chosen by DCs. And the most fashionable policy instrument chosen has been the VERs, ironically described as 'voluntary' but, in fact, imposed on reluctant exporting countries threatened with more drastic treatment in the absence of the VERs. And the most serious of the VERs, those on cotton textiles, have been formally signed multilaterally into continuing quantitative restrictions under the LTA. 
Table 2. Invoking of GATT clause XIX until 1970

Application of Paragraph 1 in specific cases

Australia

Alloy steels

Antibiotics

Casual footwear

Copper brass sheet and strip

Forged steel flanges

Four-wheel-drive vehicles

Heat-resisting glassware

Knitted coats, jumpers, cardigans, sweaters and the like

Knitted shirts

Linseed oil

Motor mowers

Piecegoods, woollen

Polyethylene and polypropylene twine, cordage, rope and cable

Printed cotton textiles

Refrigerating appliances, parts of

Timber

Austria

Chicken eggs

Matches

Oilcakes

Porcelain

Canade

Corn

Frozen peas

Potatoes

Strawberries

Turkeys

France

Foundry pig iron

Horse meat

Germany, Fed. Rep. of

Hard coal and hard coal products Petroleum and shale oil
Concession suspended

Introduction of restriction

Removal of restriction

Introduction of restriction

Removal of restriction

Introduction of restriction

Removal of restriction

Concession suspended

Renegotiation under Article XXVIII

Introduction of restriction

Concession suspended

Renegotiation under Article XXVIII

Introduction of restriction

Introduction of restriction

Concession suspended

Renegotiation under Article XXVIII

Introduction of restriction

Removal of restriction

Concession suspended

Renegotiation under Article XXVIII

Introduction of restriction

Removal of restriction

Introduction of restriction

Removal of restriction

Concession suspended

Renegotiation under Article XXVIII

Introduction of restriction

Removal of restriction

Introduction of restriction

Removal of restriction

Introduction of restriction

Removal of restriction

Concession suspended

Concession restored

Concession suspended

Temporary compensation

Introduction of special valuation

Termination of special valuation

Concession suspended

Concession restored

Introduction of special valuation

Compensation to United States and termination of special valuation

Concession suspended

(Concession restored after expiry of time limit)

Introduction of special valuation

Termination of special valuation

Concession suspended

Introduction of restriction

Introduction of restriction

Introduction of restriction 
Greece

Apples

Electric refrigerators

Tyres.

Italy

Foundry pig iron

Raw silk

Nigeria

Cement

Peru

Lead arsenate and valves for industrial purposes

Rhodesia and Nyasaland

Cotton and rayon piecegoods

Spain

Cheese

Synthetic rubber

United States

Alsike clover seed

Bicycles

Clinical thermometers

Cotton typewriter ribbon cloth

Dried figs

Hatters' fur

Lead and zinc

Pianos

Safety pins

Sheet glass

Spring clothes pins

Stainless steel flatware

Toweling of flax, hemp or ramie
Concession suspended

Renegotiation under Article XXVIII

Concession suspended

Renegotiation under Article XXVIII

Concession suspended

Partial restoration

Concession suspended

Introduction of restriction

Partial removal of restriction

introduction of restriction

Concessions suspended

Introduction of restriction

Removal of restriction (by Rhodesia)

Introduction of restriction

Concession suspended

Compensation to United States

Compensation to Canada

Compensation to EEC

Concession suspended

Concession restored (after expiry of extension)

Concession suspended

Renegotiation under Article XXVIII

Concession suspended

Concession restored

Concession suspended

Compensation to United Kingdom

Concession restored

Concession suspended

Renegotiation under Article XXVII

Concession suspended

Concession restored

Introduction of restriction

Removal of restriction

Concession suspended

Concession suspended

Compensation to United Kingdom and Fed. Rep. of Germany

Concession restored

Concession suspended

Compensation to United Kingdom

Compensation to Japan

Partial restoration

Compensation to Sweden

Concession suspended

Renegotiation under Article XXVIII

Concession suspended

Partial restoration

Concession restored

Concession suspended

Compensation to United Kingdom, Belgium, Netherlands

Renegotiation under Article XXVIII 
Wilton and velvet carpets

Women's fur felt hats and hat bodies
Concession suspended

Compensation to United Kingdom

Compensation to Japan

Partial restoration

Concession suspended

Renegotiation under Article XXVIII

Application of Paragraph 3 in specific cases

Belgium

Suspension of concession on mastics in connection with United States' action on hatters' fur

Concession restored

European Economic Community

Suspension of concession on varnishes and lacquers in connection with United States action on Wilton carpets and glass

Partial restoration of concession

Turkey

United States

Suspension of concessions on various articles in connection with United States action on dried figs

Proposed suspension of concessions on various articles in connection with Austria's action on oilcakes (not implemented)

Agreement for maintenance of obligations and rights between Austria and United States

Source: Analytical Index, Third Revision (March 1970). Notes on the Drafting, Interpretation and Application of the Articles of the General Agreement, GATT (1970-71, pp. 109-114).

Note: Further details on these cases, including dates of introduction, termination or renegotiation, plus whether tariffs or QRs were imposed, are available at the GATT Secretariat, in unpublished form.

Table 3. The relationship between Japanese voluntary export restraints and United States escape-clause investigations

\begin{tabular}{lcc}
\hline $\begin{array}{l}\text { Items subject to } \\
\text { Japanese voluntary } \\
\text { export restraints }\end{array}$ & $\begin{array}{c}\text { Items in previous } \\
\text { escape-clause } \\
\text { action }\end{array}$ & $\begin{array}{c}\text { Finding in previous } \\
\text { escape-clause } \\
\text { action }\end{array}$ \\
\hline
\end{tabular}

1. Bicycle parts

2. Malleable cast-iron joints

3. *Bicycles, assembled

$$
\begin{aligned}
& \text { Bicycle parts } \\
& \text { Cast-iron soil-pipe } \\
& \text { fittings }
\end{aligned}
$$

Bicycles
Negative

Negative

First investigation: Negative

Second investigation: Positive (President invoked escape clause)

Third investigation: Negative 


\begin{tabular}{|c|c|c|}
\hline 4. Thermometers & Clinical thermometers & $\begin{array}{l}\text { Positive (President } \\
\text { invoked escape clause) }\end{array}$ \\
\hline 5. *Wood screws & Wood screws & $\begin{array}{l}\text { First investigation: } \\
\text { Negative* } \\
\text { Second investigation: } \\
\text { Negative } \\
\text { Third investigation: } \\
\text { Evenly divided } \\
\text { (President declined to } \\
\text { invoke escape clause) }\end{array}$ \\
\hline $\begin{array}{l}\text { 6. Gloves, woollen, } \\
\text { knitted }\end{array}$ & $\begin{array}{l}\text { Knit gloves and } \\
\text { mittens, wool }\end{array}$ & $\begin{array}{l}\text { Disinissed (at applicant's } \\
\text { request) }\end{array}$ \\
\hline $\begin{array}{l}\text { 7. Scarves, silk and } \\
\text { rayon }\end{array}$ & $\begin{array}{l}\text { Screen-printed silk } \\
\text { scarves }\end{array}$ & $\begin{array}{l}\text { Positive (President } \\
\text { declined to invoke } \\
\text { escape clause) }\end{array}$ \\
\hline 8. Silk fabrics & Silk woven fabrics & $\begin{array}{l}\text { Dismissed (after pre- } \\
\text { liminary inquiry) }\end{array}$ \\
\hline $\begin{array}{l}\text { 9. Flatware, stainless } \\
\text { steel }\end{array}$ & $\begin{array}{l}\text { Stainless steel table } \\
\text { flatware }\end{array}$ & $\begin{array}{l}\text { Positive (President } \\
\text { invoked escape clause) }\end{array}$ \\
\hline $\begin{array}{l}\text { 10. Gloves and mittens, } \\
\text { baseball use }\end{array}$ & $\begin{array}{l}\text { Baseball and softball } \\
\text { gloves }\end{array}$ & $\begin{array}{l}\text { Positive (President } \\
\text { declined to invoke } \\
\text { escape clause) }\end{array}$ \\
\hline I. Raincoats, vinyl & Plastic raincoats & Negative \\
\hline 2. Smoking accessories & $\begin{array}{l}\text { Tobacco pipes and } \\
\text { bowls }\end{array}$ & $\begin{array}{l}\text { Positive (President } \\
\text { declined to invoke } \\
\text { escape clause) }\end{array}$ \\
\hline $\begin{array}{l}\text { 13. Tableware, hard } \\
\text { porcelain }\end{array}$ & $\begin{array}{l}\text { Household china } \\
\text { tableware }\end{array}$ & Negative \\
\hline 14. Umbrellas & Umbrellas & $\begin{array}{l}\text { Dismissed (at applicant's } \\
\text { request) }\end{array}$ \\
\hline 5. *Umbrella frames & Umbrella frames & $\begin{array}{l}\text { First investigation: } \\
\text { Positive (President } \\
\text { declined to invoke } \\
\text { escape clause) } \\
\text { Second investigation: } \\
\text { (Dismissed at appli- } \\
\text { cant's request) }\end{array}$ \\
\hline $\begin{array}{l}\text { 16. * Glass and crystal } \\
\text { ware }\end{array}$ & Handmade Glassware & $\begin{array}{l}\text { First investigation: } \\
\text { Evenly divided } \\
\text { (President declined to } \\
\text { invoke escape clause) } \\
\text { Second investigation: } \\
\text { Negative* }\end{array}$ \\
\hline $\begin{array}{l}\text { 17. Rosaries } \\
\text { 18. Tiles, mosaic, } \\
\text { unglazed }\end{array}$ & $\begin{array}{l}\text { Rosaries } \\
\text { Ceramic mosaic tiles }\end{array}$ & $\begin{array}{l}\text { Negative } \\
\text { Positive (President } \\
\quad \text { declined to invoke } \\
\text { escape clause) }\end{array}$ \\
\hline
\end{tabular}

Source: Constructed from Lynch (1968, p. 200) and Kelly (1963, pp. 169-173) by John Cheh (1974, Table VI-2).

* Where a product had been subjected to more than one escape-clause investigation, we write the finding in italics.

Before discussing the scope of these VERs, it is interesting to note that an analysis of the US VERs, as in Table 3, shows how industries that failed to win protection by the escape clause route then proceeded, through executive action, to secure VERs on imports (from Japan) - the correlation is revealing. At the same time, note that several industries with VERs have not even bothered to go the escape clause route first; this is true, for example, of cotton textiles in the US, now under the LTA! In fact, the great advantage of VERs is that the industry does not have to satisfy the relatively stringent requirements such as the demonstration to an officially-designated agency (e.g. the US Tariff Commission) of serious injury from concession-led increase in imports: all that is truly necessary is sufficient political clout with 


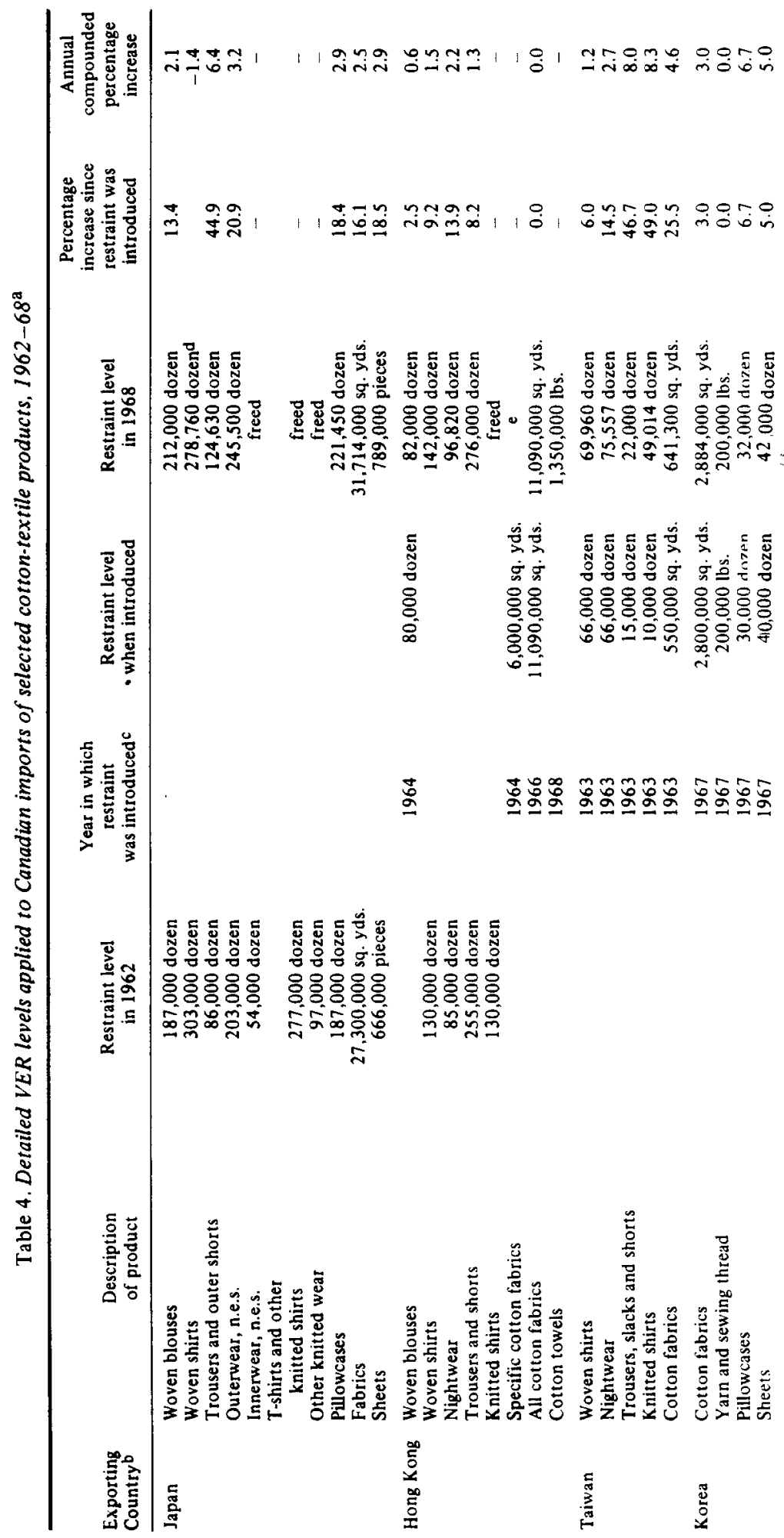




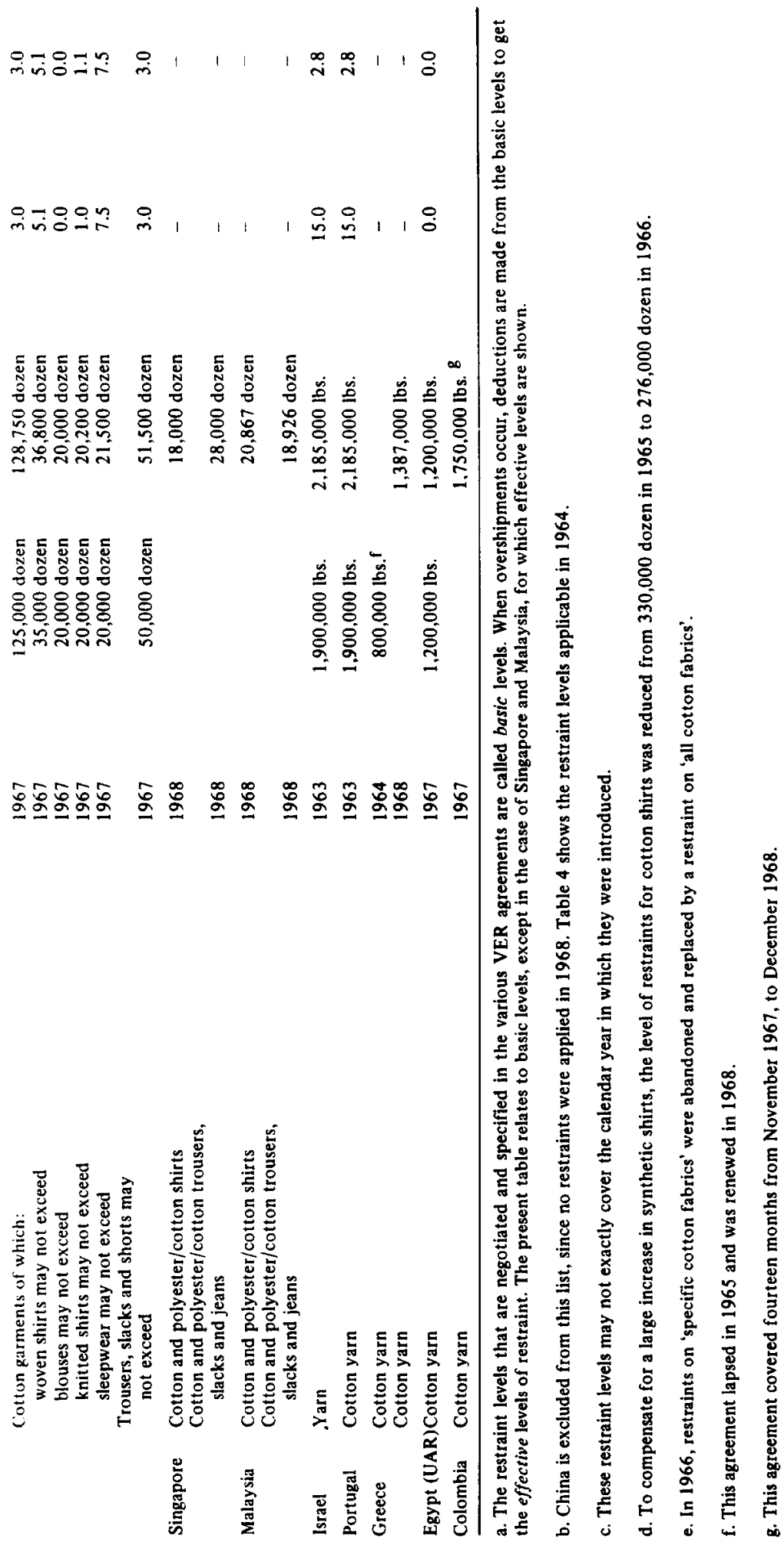




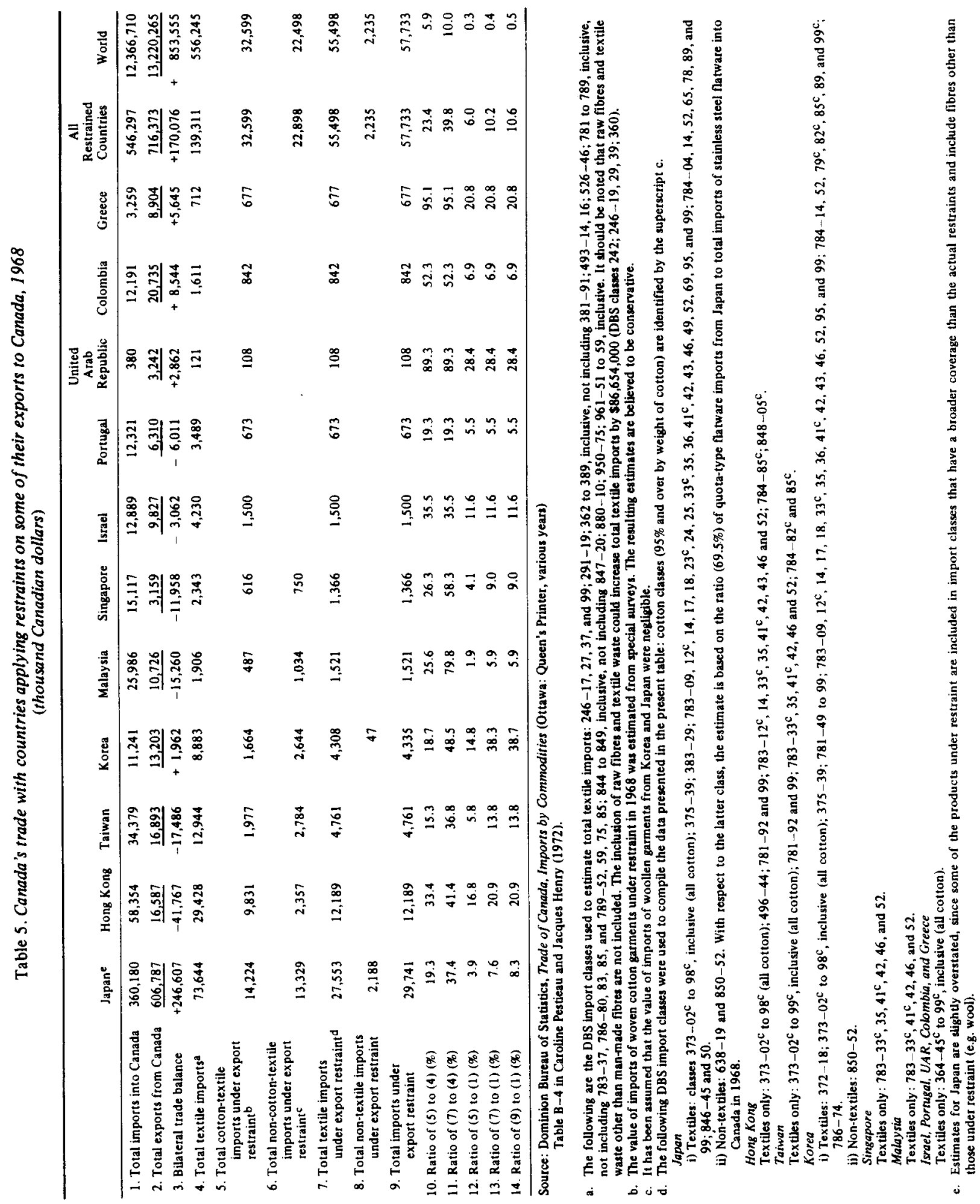


one's government and, in turn, the latter's clout with the government and/or traders of the exporting countries. As Metzger has put it pointedly in relation to the historical Potato Agreement of 1948 between the US and Canada, an early example of VERs:

On the US side, strong domestic interests desired to protect themselves against competitive imports. They either believed that they could not qualify for escape clause relief (i.e. Cotton Textiles, Manmade Textile Fibres, Shoes), or, if they might qualify for National Security Amendment relief (i.e. Steel), they were aware of the foreign relations problems involved in imposing unilateral quotas, which are often considered to be 'unfriendly' acts by America's trading partners. Cognizant Congressional Committees, made aware of these problems by their own experience no less than by that communicated by the Chief Executive, have not desired to force the Administration's hand by passing mandatory legislative quotas; indeed, they have had grave doubts that in the last analysis they could muster the strength to repass such a bill over a determined Chief Executive. Yet they, like the Administration, have been loath to treat all domestic industries - those with and those without major political strength-alike. Those without sufficient domestic political strength have simply had to live with the foreign competition which cannot be stemmed under generally applicable domestic legal criteria. Those with such strength have secured the extraordinary remedy of the United States raising to the highest international negotiating levels the matter of securing curtailment of imports from friendly foreign countries, developing and developed alike, in the interest of those who cannot show, or at any rate have not attempted to show, serious injury in consequence of increased importation.

Indeed, similar exertion of political muscle by industry and, in turn, by government against the exporting country were to mark the four early VERs between Japan and the US in the 1930s. ${ }^{16}$

Information regarding VERs is, by the standards of international trade data, occasionally difficult to come by: this is in the nature of the case, given the extra-GATTframework, political arm-twisting that precedes their incidence. Such data as are available for Canada have been put together by Henry and reproduced here in Tables 4 and 5 . Table 4 relates exclusively to cotton textiles and shows both the specific nature of the quotas and the negligible growth rates allowed in them annually in nearly all cases. Table 5 gives for 1968 the countrywise incidence of VERs, extends the data to non-textiles and shows that even (from Canada's viewpoint) the most favourable ratio of total imports under VERs to total imports, runs as high as $38.7 \%$ for Korea, $28.4 \%$ for the UAR and almost $21 \%$ for Hong Kong and Greece. ${ }^{17}$

For the United States, on the other hand, we have Magee's estimates which are seen, in Table 6 , to yield an estimated value of trade (affected by VERs) as exceeding $\$ 5$ billion in 1971 - a figure that, as one would expect, exceeds greatly the Canadian 1968 estimate of $\$ 57$ million (Canadian).

On the other hand, Canada and the United States are only two of many DCs practicing VERs. This is seen most clearly from Table 7 which gives the list of Japanese VERs, other than the major ones on textiles and steel, by country of destination for July 1971.18 And, of course, many DCs are party to the VERs on textiles and steel.

By far the most important existing, as distinct from potential, VERs relate to textiles and currently are embodied in the Arrangement Regarding International Trade in Textiles, negotiated by some 50 governments in 1973 and entering into force on 1st January 1974. This arrangement goes back proximately, in essence, to the initial Short-Term Arrangement (STA) that was negotiated in 1961 at US initiative and remained in force between October 1961 and September 1962, and which then was to be succeeded by the LTA which was to be repeatedly renegotiated. The original agreements were restricted to cotton textiles whereas the latest agreement extends to 'wool, man-made fibres, or blend thereof'. 19

Table 6. Major US imports subject to voluntary export restraints and import quotas, 1971 (Millions of Dollars)

\begin{tabular}{|c|c|c|}
\hline & VERs & $Q R s$ \\
\hline $\begin{array}{l}\text { Petroleum } \\
\text { Sugar } \\
\text { Dairy products }\end{array}$ & & $\begin{array}{r}3,278 \\
813 \\
70\end{array}$ \\
\hline Total & & $\overline{4,161}$ \\
\hline $\begin{array}{l}\text { Cotton textiles } \\
\text { Synthetic and woollen textiles } \\
\text { Steel } \\
\text { Meat }\end{array}$ & $\begin{array}{c}590 \\
1,840 \\
2,009 a \\
598\end{array}$ & \\
\hline Total & 5,037 & \\
\hline
\end{tabular}

Source: Stephen P. Magee (1972, p. 662); cited also in Fred Bergsten (1975).

a. 1969 figure, excluding several categories of steel products covered by the VERs. Thus the figure for total VER coverage should be somewhat higher. In 1973 , the total coverage approximated $\$ 2.3$ billion. 
Table 7. Japanese voluntary quantitative export controls on products, other than textiles and steel, by country of destination, as of July 1971*

\begin{tabular}{l} 
Articles \\
\hline Bicycles \\
Stainless steel knives, forks and spoon
\end{tabular}

Silk fabrics

Zoris made of rubber sponge

Umbrellas

Umbrella ribs and stretchers

Baseball or softball gloves and mitts

Badminton rackets and frames

Ceramics (tableware, kitchen utensils, personal effects, ornaments, smokers' supplies, toys, stationery it

Glazed ceramic wall tile $\nmid$

Ceramic mosaic tiles

Flatware

Iron and steel wood screws

Frozen swordfish

lodine and iodine products

Binoculars

Household sewing machines

Canned mandarin oranges

Fresh mandarin oranges $\dagger$

Tuna, canned in brine

Fresh or frozen tuna

Batteries with manganese layer

Polyvinyl chloride leather

Knives (kitchen, pocket, hunting and carving) $\dagger$

Apples $\dagger$

Polychloride resins $\dagger$

Rubber shoes (excluding rubber beach sandals) and shoes made of textiles with rubber soles
Countries of Destination

United States, Canada, and Mexico

United States, Australia, Austria, Belgium, Canada, Denmark, W. Germany, Finland, France, Greece, llong Kong, Ireland, Italy, Luxembourg, Malaysia, Netherlands, Norway, New Zealand, Panama, Portugal, Rep. of Korea, S. Vietnam, Singapore, Spain, Sweden, Switzerland, Taiwan, Thailand and the United Kingdom

All countries, except Iran, Iraq, Nansei Islands, Okinawa, S. America and Africa

United States and Canada

United States, W. Germany, France, Italy, Belgium, Netherlands and Luxembourg

United States, France, Italy, W. Germany, Belgium, Netherlands and Luxembourg

United States, Canada and Hawaii

United States, Italy, France, W. Germany, Belgium, Netherlands and Luxembourg

All countries, except U.K., Iran, Iraq, Nigeria, S. Rhodesia and Nansei Islands United States and Benelux

United States, W. Germany and Canada

All countries, except Iran, Iraq, Nigeria, S. Rhodesia and Nansei Islands

United States, Norway, Sweden, U.K., Denmark, Ireland, Benelux, France, W. Germany, Switzerland, Portugal, Spain, Italy and Austria

United States and Canada

All countries, except Nansei Islands

All countries, except Nansei Islands

United States and Canada

United States, U.K., Canada, Belgium, W. Germany, Netherlands, Luxembourg, France, Italy, Sweden, Norway, Ireland, Switzerland and Denmark

Canada

United States

American Samoa. British and French New Hebrides, Malaysia and Dutch St. Martin Island

France, Italy, W. Germany, Belgium, Netherlands, Luxembourg, Switzerland and Sweden

Australia

United Kingdom

Taiwan, Hong Kong, Macao, S. Vietnam, Thailand, Malaysia, Singapore and the Philippines

All countries, except African cuuntries (other than the UAR and Rep. of S. Africa), United States and Nansei Islands

Benelux

Source: Department of State Airgram Number A-567 from American Embassy in Tokyo dated 21 July 1971; and the US Tariff Commission.

- In addition to the items listed above as having voluntary quantitative export controls, the following items have both export and domestic shipment controls: cellophane, high quality paper, coated paper, rolled light metal products, selenium, malleablé cast iron joints, shovels, scoops, western style farm instruments, gas pipe, fence tube, ferro-chromium, ferro-manganese, dry batteries, $8 \mathrm{~mm}$. film, editing machines, TV receivers, sulphur, paint, explosives, caustic soda, methanol, acetic acid, soda sulphide, and certain polyethylene resins.

$\$$ In addition to quantitative restrictions, other factors are controlled, such as price, design, evidence of bona fide importer, and type of transaction. 
The VERs, including the Arrangement in regard to Textiles, suggest certain broad characteristics and conclusions.

(i) They can be invoked successfully at extremely low levels of imports, both absolutely and as a share of domestic absorption. Thus, the early VERs on textiles from Japan, imposed by the US in the 1930s, were at a time when total imports of textiles into the US were no more than $3 \%$ of domestic production and total imports from Japan were only about $1 \% .^{20}$ During 1951-62, straddling the renewal of such VERs in mid-1950s, the shares were, if anything, even lower. Similarly, the steel VERs invoked by the US have also been in the face of imports as low as 17 million tons against domestic production of 141 million tons in $1969 .^{21}$

(ii) The industries profiting from VERs almost always allege fears of 'low-price' imports offering undue competition and threatening injury, rather than actually causing it. ${ }^{22}$

(iii) The length of duration of the VERs, at a time, would seem to be around one year but can go to as far as five years. In several cases, they have been renewed beyond the period of first imposition. ${ }^{23}$ Some have been allowed to lapse as well.

(iv) The VERs are an inefficient instrument, compared to domestic tariffs or quotas, in restricting imports. The principal cause is that VERs apply to specific exporters and they cannot effectively rule out new suppliers from entering the market. In consequence, the progress of most VERs on specific countries (with notable exceptions as in the case of US VERs on steel) has been towards increasing coverage of other exporters and, in the case of textiles, to a fully multilateral arrangement of exporters and importers. ${ }^{24}$ In other cases, such as Canada, there is 'back-up' legislation in case VERs fail to hold back imports effectively. ${ }^{25}$

(v) While the VERs build in permissible rates of growth of exports from specific countries, these are invariably controlled at low levels. Thus the latest Arrangement on Textiles builds in a ceiling of $6 \%$ (as against the earlier $5 \%$ ) but, at the same time allows for an escape route (seized under the earlier Arrangement by Canada, for example, at $3 \%$ ) under which a 'lower positive growth rate may be applied'. ${ }^{26}$

(vi) Furthermore, there is literally no sanction against the expansion of capacity in the domestic industry of the importing country while the VERs operate. This is the case even for the 1974 Arrangement in Textiles; and, in fact, while the earlier LTA operated, the exported LDCs noted and complained about the growth of such capacity in member DCs to no avail. Therefore VERs are, in this respect, one-sided.

(vii) Finally, unlike the compensation possibility in the GATT Article XIX, there is practically no evidence that any of the existing and past VERs have incorporated explicit compensation to the countries whose export markets are being disrupted. ${ }^{27}$

\section{IMPACT OF 'EXPORT MARKET DISRUPTION' ON WELFARE OF EXPORTING LDCs}

The threat of protectionist restrictions being invoked by the importing countries, on grounds of market disruption, can be shown to impose a welfare loss on the exporting countries, as is in fact done in the theoretical Appendix II.

It is shown there that, taking expected utilities, economic welfare of the exporting country will be less than if there were no such threat. It is also shown that if the exporting country, in turn, reacts with an optimal policy intervention in the nature of restricted exports so as to reduce the probability of VERs or other such market-disruption-related restrictions being invoked, then the reduction in welfare from the threat of such invocations will be less than if the exporting country took no such action: but the loss will still be there. And, furthermore, if investment allocations cannot be costlessly readusted, once in place, then the presence of such 'adjustment costs' will further increase the loss of welfare from the threat of such trade restraints. Finally, the actual invoking of the trade restraints would inflict a welfare loss on the exporting country that would exceed the expected loss from the threat of such an invocation at a future date.

From these general theoretical propositions, certain compensatory proposals would seem to follow.

(1) First, there is a case for asking importing DCs to compensate the exporting LDCs faced with mere threats of market-disruption-related trade restraints. The DCs can reasonably be asked to 'buy', with compensation payments, the right to invoke a market-disruption-related trade restraint on a product, and to forego the right to resort to such trade restraints on all products not so bought for. Thus a list of 'restrainable' items can be prepared under multilateral auspices, such as GATT, and the compensation required for affected exporters, whose welfare is correspondingly reduced, would have to be paid to put a product on such a list. 
(2) Second, the actual invoking of such restraints, by imposing a greater loss, would equally call for further compensation to the affected exporters.

Compensation, for potential and actual export market disruption, to the exporting countries affected by trade restraints related to market disruption would thus be the natural consequence of our analysis. In the next section (V) therefore, we consider the possible rules in this regard in greater depth, proceeding in the final section (VI) to consider the implications that these rules would have for modifications in GATT Article XIX and related provisions.

\section{COMPENSATION FOR EXPORT MARKET DISRUPTION, POTENTIAL AND ACTUAL: SUGGESTED RULES}

The rules for compensation for marketdisruption-related trade restraints can then be defined on a number of dimensions as follows.

\section{(1) Penalty/compensation for potential restriction}

In accordance with the arguments of the preceding section, a list of items potentially subject to market-disruption-related trade restrictions' ought to be maintained. This list may be described as the List of Potentially Restrainable Items. ${ }^{28}$ For putting an item on such a list, the DCs would be required to pay a 'penalty' which can be utilized to compensate the exporting countries subject to welfare loss from the threat of trade restraints on the item.

(2) Penalty/compensation for actual invoking of trade restraints on potentially restrainable items

Moreover, as and when the trade restraints are actually invoked, there should be a further penalty which should be used for compensating the exporting country whose export market is thus restrained. ${ }^{29}$ The penalty so imposed, if it is to reflect the compensation to be paid to the exporting countries, must then be less than the actual cost of the trade restraint by the adjusted sum already paid for putting the item, in the first place, on the list of potentially restrainable items.

\section{(3) Escape clause from list of potentially restrainable items}

While the preceding two rules should, in principle, divide all items into those that are restrainable and those that are not, this is politically inadequate. There will almost certainly be cases where unforeseen and politically unmanageable difficulties will arise on items not already put on the list of potentially restrainable items and the DC of importation will be unable to avoid responding to political pressures for trade restraint.

An escape clause action for items not on this list would therefore be appropriate. At the same time, given the fact that this should not provide an incentive to escape from the option of putting such items on the restrainable list, it would be equally appropriate to make the invoking of this escape clause both more difficult and more costly. Thus, the escape clause should require that the importing $D C$ be allowed nonetheless to invoke a trade restraint on items not on the list of potentially restrainable items, provided that $(i)$ it makes a demonstrable case, under multilateral (GATT) auspices, of the existence of serious injury (as under the current GATT Article XIX) and (ii) it then makes a considerably larger penalty payment for the compensation of the exporting countries. It may also be noted further that one would, in practice, need a substantial time limit for an item to be on the restrainable list before permitting the invoking of trade restraints under it. Otherwise, as when this period could be a few weeks or months, it would pay countries to go this route rather than the proposed escape clause route where the proposed penalties are higher.

\section{(4) Automaticity of compensation}

The penalty/compensation would be automatic under the preceding rules, rather than constituting a mere possibility as in the current GATT Article XIX. This would rule out the use of political muscle to get out of this obligation when invoking trade restraints.

\section{(5) Financial form of compensation}

Moreover, the above rules require financial compensation. This is in contrast, for example, to the Article XIX variety of 'compensation', which takes the form of either grant of a new tariff concession (on something else) or of withdrawal of a tariff concession by the exporting country. This latter method reflects the tariffbargaining framework in which GATT rules are enmeshed; it makes little sense since compensation to the exporter in the form of enabling the latter to raise a tariff in retaliation, for example, presupposes that the latter is advantageous while in fact, it is likely to cause yet more damage by further restraining trade; at the same time, it disrupts yet another market in seeking redress for the original market 
disruption. The financial form of penalty/ compensation provided for in the rules suggested above is free from these obvious defects.

\section{(6) Compensation to exporting country}

Furthermore, the financial compensation is designed here for payment to the exporting country, rather than to the exporting industry: as called for by the theoretical analysis of Appendix II. In turn, the payment is to be made by the importing country. It may be noted that the latter financial penalty to be paid from the budget would, in turn, serve to generate executive counter-pressures against the industrial pressure groups for trade restraints, potential and actual.

\section{(7) Compensation only for $L D C s$}

The preceding rules in regard to compensation may be applied only to exporting LDCs. They are, after all, the countries which have been seriously affected by the textiles restrictions and by VERs, as we have already seen. ${ }^{30}$ Further, there is greater willingness, as part of the new international economic order, to grant LDCs reasonable accommodation via framing new rules regarding their trade. Moreover, the flows of funds to be so generated are far more likely to be significant, relative to their needs, for LDCs than for DCs. Finally, discriminatory adjustment of trade rules, in favour of LDCs, is well-embedded in GATT reform, as in the enactment of Article XXIII for them at GATT.

The foregoing set of rules, involving essentially compensation for exporting LDCs by importing DCs, are not entirely novel in their reference to the potential use of trade restraints since the well-established practice of the 'binding' of tariffs indeed implies that the potential use of restrictions is given up. In regard to the notion of the compensation itself, however, there are no obvious precedents. However, a precedent of sorts, which certainly suggests that what is being proposed here is fully feasible, relates to the payment by the United States of compensation to the Turkish government of a sizeable sum in order to enforce the ban on poppy production: by using this money to compensate Turkish farmers, in turn, this would theoretically have made it possible for them to shift to other cultivation at no financial loss. ${ }^{31}$ This 'precedent' is spelled out in some detail in Appendix I. There would therefore appear to be nothing insuperable, politically, in putting the suggested compen- satory rules here onto the agenda for GATT reform.

At the same time, it would be useful to note that, in complementarity to the rules suggested above, two DC policies would be extremely valuable, only one of which is being gradually extended in scope:

(1) Insofar as the response to foreign imports, or to domestic decline due to other reasons, is to provide domestic adjustment assistance to assist factors of production to retrain and relocate, this will correspondingly reduce the need to resort to trade restraints by making the pressures for such restraints from the industry both less intense and politically less difficult to resist. In this regard, the easing of the criteria for such adjustment assistance in the recent US Trade Act of 1974 is welcome news for the exporting LDCs. ${ }^{32}$

(2) Next, it is clear from elementary principles that trade restraint, to protect the production level of the domestic industry, is inferior to the use of a production subsidy: from the viewpoint of the importing DC itself. ${ }^{33}$ Equally, it is obvious that the use of the production subsidy will increase the overall market in the DC for the imported item while a tariff, by increasing the price for consumers, will reduce it. Hence, given the fact that domestic production must be maintained at a desired level, the use of a production subsidy by the importing DC will be preferable, from the viewpoint of the exporting LDC, than the use of a trade policy. ${ }^{34}$ Thus it would be useful if the overall reform in regard to the phenomenon of market-disruption-related trade restraints, as suggested in this section, were to include a multilateral agreement by DCs to use production subsidies rather than tariffs or trade quotas, whenever trade restraints are invoked under the rules specified above. ${ }^{35}$ The only exceptions to this code could include emergency situations where an immediate trade quota may be necessary: in this case, the quota could be phased out and replaced gradually by a production subsidy on a multilaterally agreed schedule.

\section{PROPOSED MODIFICATION IN GATT ARTICLE XIX}

If the suggested rules in Section $\mathrm{V}$ are to be implemented, the logical place for them is the GATT; and there, the logical candidate for replacement by these rules is Article XIX.

The GATT is being already reexamined - as, in fact, it has been continuously 
since its inception in regard to new phenomena such as the growth of customs unions - in regard to the manifestation and growth of new problems such as the use of export quotas, ${ }^{36}$ for example, to hold back commodities for national objectives such as anti-inflationary policy. The recent thrust towards a new international economic order also provides an ideal climate to re-examine long-standing issues such as market disruption which have been addressed but for which suitable solutions have not been provided.

The rules suggested in Section $V$ above therefore provide an agenda for replacing the basic content of Article XIX, in an international economic climate where such a concrete proposal is likely to be examined without immediate hostility on the part of DCs. At the same time, in being concrete and specific, the suggested changes provide the necessary content and shape to the longstanding demands by LDCs that something be done about the phenomenon of marketdisruption-related trade restraints from DCs. They constitute therefore an essential and useful input into the basic agenda for reforming GATT as part of a new international economic order.

The formal adoption of such rules, replacing
Article XIX, would also have to bring the existing VERs, including the 1974 Textiles Agreement, into line with them. This would be done most naturally by formally sanctioning them, but insisting on the payment of the penalty by the importing $D C$ s to compensate the LDCs whose exports are being constrained by these restraints. Otherwise, there would be an advantage to invoking VERs prior to the reaching of agreement on the new rules. ${ }^{37}$ Also, there would be an advantage in bringing all such trade restraints under one institutional umbrella, where they can be watched, monitored and regulated according to the suggested, new rules.

The dynamics of reaching an agreement on these rules, finally, would presumably have to involve an initiative by the LDCs themselves, as they are the parties that are injured by the current and potential market-disruption-related trade restraints. The logical place for their initiative is therefore the UNCTAD, to be followed by action by the LDC members of the GATT at the GATT. The proposals advanced here certainly provide an alternative and consistent set of reform rules that need to be considered seriously alongside the suggestions concerning market disruption that have recently been aired by the LDCs. ${ }^{38}$

\section{NOTES}

1. Article XIX is one of several, so-called 'safeguard' provisions in GATT which enable the contracting parties to re-enact trade barriers for a number of specific reasons. Article VI, for example, allows the enacting of countervailing and anti-dumping duties.

\section{Cf. Stanley Metzger (1971, p. 168).}

3. It is thus well-known that the US executive has been generally more liberal on trade barriers reduction than the US Congress and the VERs were imposed often so as to prevent more serious protectionist legislation from becoming enacted in the Congress.

$$
\text { 4. Metzger, (1971, p. 173). }
$$

5. This notion of market disruption as occurring whenever the domestic industry loses its relative share in the domestic market is implicit or explicit in trade legislation introduced earlier in the US House of Representatives. Thus HR 2511, introduced on 8 January 1969, begins typically as follows: "A Bill to provide for the orderly marketing of flat glass imported into the United States by affording foreign supplying nations a fair share of the growth or change in the United States flat glass market...' (91st Congress, 2nd Session, Committee Print, Committee on Ways and Means, US House of Representatives, June 1970, US Government Printing Office, Washington, 1970 , p. 172 (italics inserted]). Or take HR 993 which begins with: 'A Bill to provide for an equitable sharing of the United States market by electronic articles of domestic and of foreign origin ...' (ibid., p. 150 [italics inserted]).

6. See Caroline Pestieau and Jacque Henry (1972, pp. 139-140). The work referred to here is by Henry.

7. Thus, according to Pestieau and Henry (1972), Canada had official VERs in 1971 with 20 countries, of which only 6 were DCs.

8. Thus a Working Party at GATT had concluded that developments occurring after the negotiation of the relevant tariff concession which it would not be reasonable to expect that the negotiations of the country making the concession could and should have foreseen at the time when the concession was negotiated'. Cf. GATT (1970-71, p. 107). 


\section{9. ibid.}

10. ibid. In fact, in the case of Germany, in regard to hard coal, the 1958 invoking of Clause XIX was in force as late as 1975 .

11. The Article builds in provision for consultations with interested contracting parties, which is the usual forum for granting the compensation if indeed granted. (Where the action is taken prior to consultation, the interested contracting parties may retaliate. However, such retaliation has been quite rare, having occurred only in three cases to present date.) Furthermore, as seen from Table 2, and corroborated also by unpublished tabulations at GATT, compensation is only a possibility, as noted in the text, and is of ten not provided when Article XIX is invoked. In fact, dissatisfaction with the compensation aspect of Article XIX has prompted occasional suggestions to do away with it and instead modify Article XIX so as to insist on the following of certain stricter criteria by the country invoking the Article.

12. In some cases, the action took the form of establishing minimum valuations for imports, thus effectively raising the tariff rate for items with actual values below these minimums.

13. GATT (1961b, p. 25). In fact, it was at the United States' initiative that Article XIX had been included in GATT originally.

14. Cf. GATT (1961a); also cited in Pestieau and Henry (1972, pp. 137-138), in Metzger (1971, pp. 175-176), and discussed in GATT (1961b, pp. 25-26).

\section{Cf. Pestieau and Henry (1972, pp. 137-138).}

16. Metzger (1971, pp. 170-171). 'As Henry states, the "entire story shows clearly that the US-Japan voluntary export restraint agreements of the $1930 \mathrm{~s}$ resulted mainly from American pressures and threats of unilateral, permanent, and possibly more restrictive action". "Nothing indicates", he asserts, "that this pattern has changed since". The Japanese, for their part, accepted the agreements as the most practicable means of preserving a portion of their textile exports to the United States, and in the interest of political harmony in this sphere of their relationships with the United States.'

17. Note that, ideally, one would rather examine how much trade is, in fact, inhibited at the margin by these VERs.

18. Note, however, that this list would include also VERs imposed truly voluntarily by Japan, without duress from the importing countries, in the interest of 'price regulation', quality control, etc.

19. Cf. GATT (1974), Article 12, pp. 17-18.

20. Cf. Metzger (1971, p. 170).

\section{Cf Metzger (1971, p. 182).}

22. It is interesting to note that the recent theory of nonequivalence between tariffs and quotas under uncertainty shows that if the uncertainty comes from foreign supply, the welfare-superiority of tariffs over quotas as methods of restricting imports to a given level is reversed if the tariff rate were high: precisely $100 \%$ in the case of linear supply and demand schedules. $C f$. the interesting work of Michael Pelcovits (1975).

23. Pestieau and Henry (1972) note that the duration of a formal agreenient is not identical with its incidence; occasionally, as with GATT Article XIX as well, the restriction will go into force before papers are exchanged. They also note that most Canadian VERs have duration of one year.

24. Besides, export quotas have always been known to earn the monopoly rents (from restriction) for the exporters whereas domestic tariffs or quotas will earn them for the importer under competition.

25. Pestieau and Henry (1972, p. 168): 'Several Canadian laws include clauses that can be used to supplement or reinforce VERs, and the various amendments enacted in the context of the present government's textile policy lessen the previous dependence on exporters' voluntary collaboration. Prior to January 1969, subsection (7c) of section 40A of the Customs Act was used to apply special values for duty in instances where imports were found to have injured the interest of Canadian producers. However, this subsection was repealed and replaced on 1 January 1969, by the new section 8 of the Customs Tariff Act. As stated in section 37 of the Antidumping Act (1969), the new section authorizes the imposition of a surtax on imports that cause or threaten to cause injury to Canadian producers of similar or directly competitive goods. The Export and Import Permits Act has also been amended to permit unilateral imposition of import-licensing quotas to deal with problems of disruptive imports whenever VER arrangements would not be feasible. Furthermore, section 5(c) of this Act enables the federal government to control imports and "to implement an inter-governmental arrangement or commitment" clearly opening up a method of making VER arrangements more effective.

These are the powers on which the efficiency of the Canadian VER system rests'.

Examples can be found in US legislation as well, as in the Public Law 87-488 (HR 10788) which amended Section 204 of the Agricultural Act of 1956 by the insertion of the following sentence:

'In addition, if a multilateral agreement has been or shall be concluded under the authority of this section among countries accounting for a significant part of world trade in the articles with respect to which the agreement was concluded, the President may also issue, in order to carry out such an agreement, regulations governing the entry or 
withdrawal from warehouse of the same articles which are the products of countries not parties to the agreement.'

This legislation was approved on 19 June 1962.

Note that both US and Canada have back-up legislation for VERs in cases of textiles and meat.

\section{Cf. GATT (1974, Annex B, p. 22).}

27. However, from a theoretical standpoint, it may be noted that VERs, as contrasted with import QRs, will transfer the monopoly rents from the trade restriction to the exporters, so that one may well consider this to constitute an implicit compensation under VER arrangement. In fact, as Bergsten has pointed out, textile quota tickets are actively sold throughout the Far East at a premium that reflects this rent. See Fred Bergsten (1975, pp. 239-271).

28. An analogue to this recommendation may be found in the practice of 'binding' tariffs in advance.

29. The loss inflicted by actual invoking of restraints is, of course well understood in the trade-theoretical literature. For measurement of the cost of sugar protectionism to exporting LDCs, for example, see the work of Snape and Johnson, reviewed in $H$. G. Johnson (1967).

30. VERs have also affected Japan seriously; and, in some cases, such as the steel VERs in the USA, the impact was felt by the developed country exporters and imports were initially diverted to developing countries which thereby benefited.

31. The compensation rules suggested for trade restraints in this paper, however, relate only to financial compensation to the exporting country, and not to the exporting industry. For other contrasts, refer to Appendix I.

32. For an excellent account of the US policies in regard to adjustment assistance, and evidence on the efforts to ease the criteria for it until 1973, see Robert Baldwin and John Mutti, 'Policy issues in adjustment assistance: the United States', in Helen Hughes (ed.) (1973), especially Section IV. Adjustment assistance in the EEC is also discussed in Chapter 7 of this volume.

33. This is one of the important policy prescriptions from the theory of optimal policy intervention in the presence of 'noneconomic' objectives and follows from the fact that the tariff imposes a consumption cost (by raising prices for consumers) which is avoided, while equally protecting domestic output, by a production subsidy. Cf. J. Bhagwati and T. N. Srinivasan (1969).

34. This conclusion would have to be modified, but is not altogether nullified, if the domestic industry wishes to maintain a certain share of sales in the domestic market. The optimal policy intervention in this case, from the DC viewpoint, would be the combination of an import tariff and a production subsidy.

35. A code of conduct, along these lines, is mentioned also by Henry, op. cit., p. 175, who states that this 'has been suggested in various places' and cites one example from Bela Balassa (1967, pp. 160-161).

36. See, in this regard, the excellent pamphlet by $\mathrm{C}$. Fred Bergsten (1974). Bergsten does not consider VERs or market-disruption problems in this study.

37. For long-standing restraints such as the Textiles Arrangement, it may be politically easier and also quite sensible to have the penalty enacted at the time of the next renewal, since there has been a short time limit on each such Arrangement.

38. The latter have been neatly summarized in UNCTAD document TD/B/C.2/R.4.

\section{REFERENCES}

Baldwin, R., and Mutti, J., 'Policy issues in adjustment assistance: the United States', in Helen Hughes (ed.), Prospects for Partnership (IBRD; Johns Hopkins University Press, 1973).

Bergsten, F., Completing the GATT: Toward New International Rules to Govern Export Controls (British-North American Committee, USA, October 1974).

Bergsten, F., On the Non-Equivalence of Import Quotas and 'Voluntary' Export Restraints, Technical Series Reprint T-009 (Washington D.C.: The Brookings Institution, 1975).

Bhagwati, J., and Srinivasan, T. N., 'Optimal intervention to achieve non-conomic objectives', Review of Economic Studies (January 1969).

Cheh, J., US Trade Policy and Short-Run Domestic Adiustment Costs, Ph.D. Dissertation (MIT, 1974).
Dominion Bureau of Statistics, Several Years, Trade of Canada, Imports by Commodities (Ottawa: Queen's Printer).

GATT, Basic Instruments and Selected Documents, 9 th Supplement, 16th and 17 th Sessions (Geneva: GATT, February 1961a).

GATT, The Activities of GATT, 1960/61 (Geneva: GATT, April 1961b).

GATT, Analytical Index, Third Revision, March 1970, Notes on the Drafting, Interpretation and Affirmation of the Articles of the General Agreement (Geneva: GATT, 1970-71).

GATT, Arrangement Regarding International Trade in Textiles (Geneva: GATT, 1974).

Johnson, H. G., Economic Policies Towards the Developing Countries (Washington D.C.: The Brookings Institution, 1967). 
Kelly, W., Studies in United States Commercial Policy (Chapel Hill, N.C.: University of North Carolina Press, 1963).

Lynch, J., Toward an Orderly Market (Sophia University, Japan; Tokyo, Japan: Voyager's Press, 1968).

Magee, S. P., 'The welfare effects of restrictions on US Trade', Brookings Papers on Economic Activity (edited by A. Okun and G. Perry) 3 (1972).

Metzger, S., 'Injury and market disruption from imports', United States International Economic
Policy in an Interdependent World, US Commission on International Trade and Investment Policy, Vol. 1 (Washington D.C.: July 1971).

Pelcovits, M., 'Tariffs versus quotas', Journal of International Economics (November 1976).

Pestieau, C., and Henry, J., Non-Tariff Trade Barriers as a Problem in International Development (Canadian Economic Policy Committee and the Private Planning Association of Canada, April 1972).

UNCTAD, Document No. TD/B/C.2/R.4.

\section{APPENDIX I}

ON COMPENSATING FOR MARKET LOSS OF A BAN: THE TURKISH POPPY AND THE UNITED STATES

Outside of the GATT Article XIX framework (where compensation is non-automatic and furthermore applies only if the market disruption being nullified is a result of 'obligations incurred by a contracting party under this Agreement, including tariff concessions', and whose applicability in any event has been emasculated by actions such as the LTA and VERs undertaken outside of its domain as noted in the text), the only major example of an importing country paying compensation to the exporting country when trade is sought to be eliminated or reduced is that of the United States paying Turkey a significant compensation to enforce the ban on Turkish poppy cultivation.

This precedent is not perfect, while illustrating what is feasible. Its major difference from the compensation proposed for export market disruption is that its objective is to induce adjustment by compensating the exporting activity so that the exports will in consequence effectively cease, whereas the proposed compensation here is when exports have already ceased (or been reduced) and the compensation is for the adjustment that has to occur with the decline in exports. This difference, of course, stems from the fact that the case deals with trade in a bad, rather than a good, and hence with illegal trade that was sought to be eliminated at source through banning the production activity itself. Its similarity, however, with the proposed compensation for export market disruption (for goods) consists in the fact that the importing country provided the compensation to the farmers in the exporting country for the adjustment necessary if the heroin trade was to be curtailed. Hence, a brief account and review of the salient features of the case of the Turkish poppy and the US adjustment assistance is relevant and follows in the rest of this Appendix.

The US had been putting pressure on Turkey to reduce poppy cultivation for a long time. In response to this pressure, the number of provinces in which cultivation was legal was reduced from 42 (out of 70 ) in 1960 to 7 in 1970 , and 4 in 1971. 1 On 30 June 1971, the US and Turkey announced a total ban on poppy cultivation. On 14 February 1974, Turkey unilaterally lifted the ban.

The logistics of the poppy trade before the ban were as follows. By a simple process poppies can be turned to opium gum, which can in turn be manufactured into morphine base. Turkey produced around $120,000 \mathrm{~kg}$ of opium gum per yr. Legally, all of this was supposed to be sold to a state marketing agency, at $\$ 13$ a kilo. But about half of the crop went on the black market, selling at around $\$ 35$ a kilo. (Refined into morphine base - a cheap process - this became $\$ 550-\$ 600$ a kilo in Marseilles.) ${ }^{2}$

The agreement to ban cultivation called for US payments of $\$ 15$ million a year, plus $\$ 20$ million for agricultural development investments in the affected regions. This was to compensate the farmers, and also the Turkish government, for the $\$ 3.5$ million a year it earned from morphine export. The Turkish marketing organization was to pay farmers a compensation of $\$ 40$ per kilo for poppies not grown. ${ }^{3}$

For more than a year after the ban, there was little impact on the flow of heroin, as dealers drew down their stockpiles. ${ }^{4}$ But eventually the ban had a major effect, doubling heroin prices in the US. ${ }^{5}$

The ban was unpopular with farmers, and 
politicians in a seven-province area agitated for an end. ${ }^{6}$ In the October 1973 elections all political parties promised to review the ban. ${ }^{7}$ When cultivation was resumed, the Turkish government said that it was because of hardships to the peasants, that it was unfair to ask Turkey to bear this burden.

It would appear that the Turkish farmers were compensated only at the legal prices presumably available on their poppy, so that the premium from illegal sales for heroin was lost by them under the ban, despite the compensation; and hence the discontent. Furthermore, it is apparent that the ban was somewhat sudden and hence little of the developmental aid was actually spent in the poppy-growing region by the time the discontent surfaced. ${ }^{8}$ Finally, the ban having been forced initially on a reluctant Turkey by the United States, which was naturally frantic to stem the heroin traffic, questions of Turkish sovereignty eventually appear to have played some role also in the termination of the ban. ${ }^{9}$

\section{NOTES}

1. New York Times (21 February 1974).

2. New York Times (9 August 1973).

3. New York Times (9 August 1973).

4. New York Times (10 October 1972).

5. New York Times (21 February 1974).

6. New York Times (9 August 1973).

7. New York Times (21 February 1974).

8. New York Times (21 February 1974).

9. Wall Street Journal (23 June 1974).

\section{APPENDIX II}

OPTIMAL TRADE POLICY AND COMPENSATION UNDER ENDOGENOUS UNCERTAINTY: THE PHENOMENON OF MARKET DISRUPTION

\section{Introduction}

The fact that 'market disruption' permits or prompts importing countries to invoke quantitative import restrictions (or, what is more fashionable in recent times, voluntary export restrictions by the exporting countries, at the urging of the importing countries) immediately implies that the exporting country faces a situation of endogenous uncertainty: where its own export level can affect the probability of such quantitative restrictions (QRs) being imposed. It simultaneously raises the following analytical questions which have obvious policy implications:

(1) What is the optimal trade policy for an exporting country which is faced by such QRintervention?

(2) Since the possibility of such QR-intervention must restrict the trade opportunity set relative to that which would obtain in the absence of the QR-possibility, can one meaningfully define the loss that such a QR-possibility imposes on the exporting country and therefore the compensation that could be required to be paid to the exporting country under, say, a modified set of GATT rules?

\section{Optimal trade policy: two-period model with} zero adjustment costs

To analyze the problem of optimal trade policy for the exporting country in the presence of market-disruption-induced possibility of QR-intervention, we will deploy the usual trade-theoretic model of general equilibrium, but will extend it to a two-period framework in Section I-IV. In Section III, we will also introduce adjustment costs, beginning with a simple formulation which has putty in period 1 and clay in period $2 .^{1}$

Thus, consider a 2-commodity model of international trade. We then assume a 2-period time horizon such that the level of exports $E$ in the first period affects the probability $P(E)$ of a quota $\bar{E}$ being imposed at the beginning of the next period. ${ }^{2}$

Let $U\left[C_{1}, C_{2}\right]$ be the standard social utility function defined in terms of the consumption $C_{i}$ of commodity $i(i=1,2)$. By assumption, it is known at the beginning of the next period whether the quota $\bar{E}$ has been imposed or not. Thus, the policy in the next period will be to maximize $U$ subject to the transformation function $F\left[X_{1}, X_{2}\right]=0$ and the terms of trade function $\pi$ if no quota is imposed and with an additional constraint $E \leqslant \bar{E}$ if the quota is imposed.

Let now the maximal welfare with and without the quota be $U$ and $\bar{U}$ respectively. Clearly then, we have $\bar{U}>\underline{U}$ when the quota is binding. 
The expected welfare in the second period is then clearly:

$$
\underline{U} P(E)+\bar{U}[1-P(E)] .
$$

The objective function for the first period therefore is:

$$
\begin{aligned}
\phi= & U\left[X_{1}-E, X_{2}+\pi E\right] \\
& +\rho[\underline{U} P(E)+\bar{U}\{1-P(E)\}],
\end{aligned}
$$

where $\rho$ is the discount factor. This is then to be maximized subject to the domestic transformation constraint, $F\left[X_{1}, X_{2}\right]=0$. In doing this, assume that $P(E)$ is convex function of $E$, i.e. the probability of a quota being imposed increases, at an increasing rate as $E$ is increased, and that, in the case where $\pi$ depends on $E, \pi E$ is concave in $E$. Then, the first-order conditions for an interior maximum are:

$$
\begin{aligned}
\frac{\delta \phi}{\delta X_{1}}=U_{1}-\lambda F_{1}=0 & \\
\frac{\delta \phi}{\delta X_{2}}=U_{2}-\lambda F_{2}=0 & \\
\frac{\delta \phi}{\delta E}= & -U_{1}+U_{2}\left\{\pi+E \pi^{\prime}\right\}- \\
& \rho(U-U) P^{\prime}(E)=0 .
\end{aligned}
$$

Now, Equations (1) and (2) yield the familiar result that the marginal rate of substitution in consumption equals the marginal rate of transformation. Equation (3) moreover can be written as:

$$
\frac{U_{1}}{U_{2}}=\left(\pi+\pi^{\prime} E\right)-\rho \frac{\{\bar{U}-\underline{U}\}}{U_{2}} P^{\prime}(E) \text {. }
$$

If (A) monopoly power is absent $\left(\pi^{\prime}=0\right)$ and if (B) the first period's exports do not affect the probability of a quota being imposed in the second period, then $\left(3^{\prime}\right)$ clearly reduces to the standard condition that the marginal rate of substitution in consumption equals the (average $=$ marginal) terms of trade. If (A) does not hold but (B) holds, then $\frac{U_{1}}{U_{2}}$ equals the marginal terms of trade $\left(\pi+\pi^{\prime} E\right)$, leading to the familar optimum tariff. If both $A$ and $B$ are present, there is an additional tariff element:

$$
\frac{\rho[\bar{U}-\underline{U}]}{U_{2}} P^{\prime}(E)
$$

This term can be explained as follows: if an additional unit of exports takes place in period 1 , the probability of a quota being imposed and hence a discounted loss in welfare of $\rho(\bar{U}-\underline{U})$ occurring, increases by $P^{\prime}(E)$. Thus, at the margin, the expected loss in welfare is $\rho(U-\underline{U}) P^{\prime}(E)$ since there is no loss in welfare if the quota is not imposed. Converted to numeraire terms, this equals

$$
\frac{\rho(\bar{U}-\underline{U}) P^{\prime}(E)}{U_{2}}
$$

and must be subtracted from the marginal terms of trade $\left(\pi+\pi^{\prime} E\right)$, the effect of an additional unit of exports on the quantum of imports. $^{3}$

It is then clear that the market-disruptioninduced QR-possibility requires optimal intervention in the form of a tariff (in period 1). It is also clear that, compared to the optimal situation without such a QR-possibility, the resource allocation in the QR-possibility case will shift against exportable production: i.e. comparative advantage, in the welfare sense, shifts away, at the margin, from exportable production. Moreover, denoting the utility level under the optimal policy intervention with quota possibility as $\phi_{Q}^{O P T}$, that under laissez faire with the quota possibility as $\phi_{Q}^{L}$, and that under laissez faire without this quota possibility as $\phi_{N Q}^{L}$, we can argue that

$$
\phi_{Q}^{O P T}>\phi_{Q}^{L} ; \phi_{N Q}^{L}>\phi_{Q}^{L}
$$

This result is set out, with the attendant periodwise utility levels achieved under each option, in Table 1 which is self-explanatory.

For the case of a small country, with no monopoly power in trade (except for the quota possibility), the equilibria under alternative policies are illustrated in Figure 1.5 Thus, $\bar{U}$ represents the utility level in the absence of a quota, $\underline{U}$ the utility level when the quota is

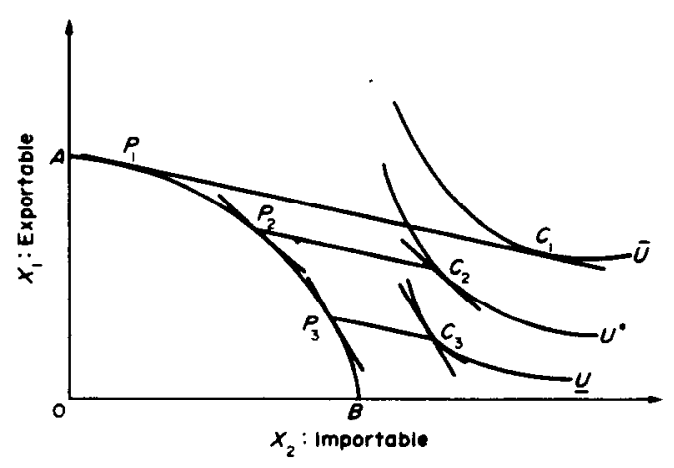

Figure 1. 
Table A1. Alternative outcomes under different policies

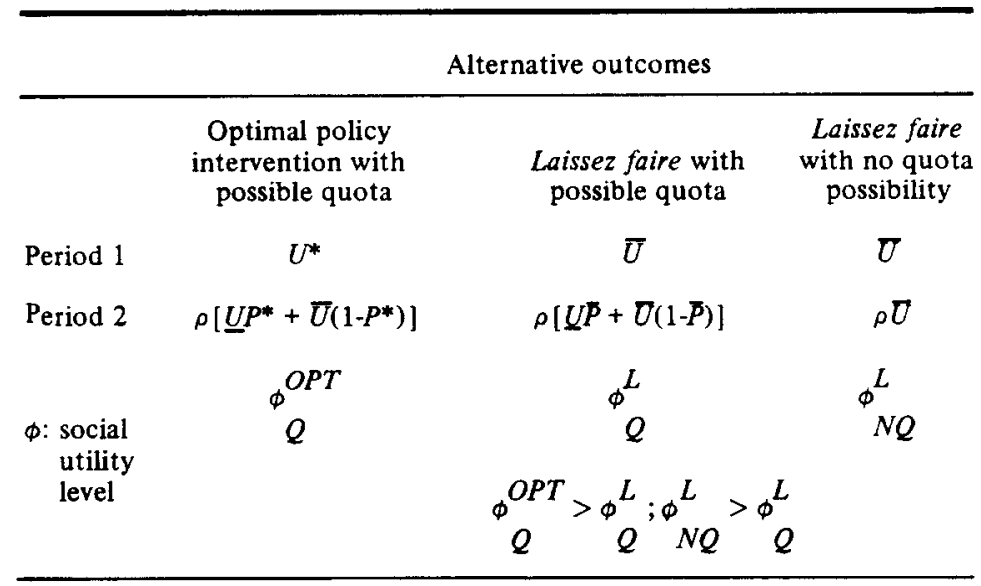

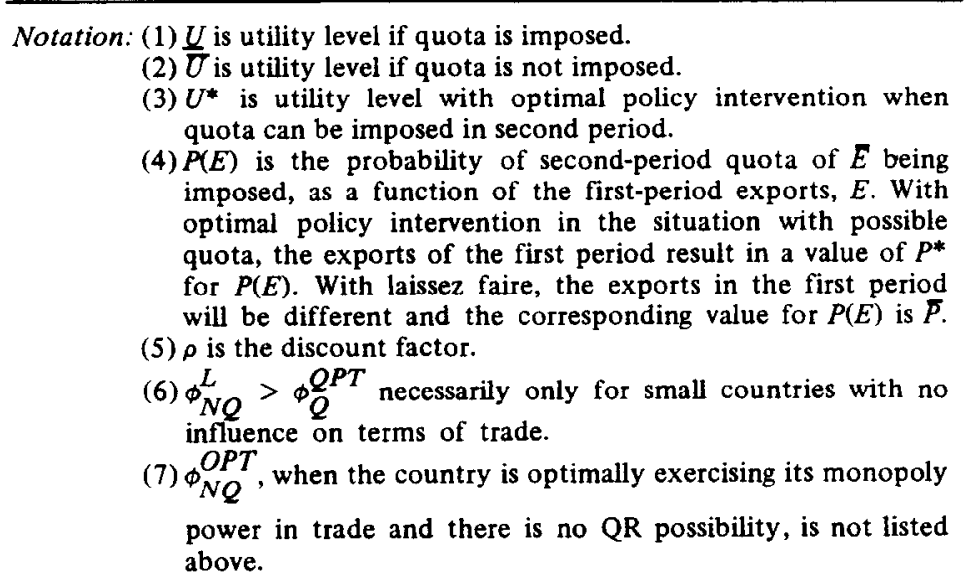

imposed, and $U^{*}$ the first-period utility level reached under the optimal policy intervention option. Note that equilibrium with $U^{*}$ naturally requires that the export level is being restricted below the level that would be reached with non-intervention (at $D$ ), while exceeding the level reached in equilibrium when the quota is invoked (at $U$ ). Also, note that the optimal policy for restricting the first-period level of exports is a tariff: a conclusion that is, of course, familiar from the theory of optimal intervention under non-economic objectives as considered in Johnson (1965) and Bhagwati and Srinivasan (1969).

\section{Defining the loss from market-disruption- induced $Q R$-possibility}

Consider now the measure of the loss to the exporting country from this possibility of a market-disruption-induced $Q R$. One can think of alternative ways in which this loss could be defined:

Measure I: Taking expected utilities, one can define the loss of welfare to the exporting country as the difference between $\phi_{N Q}^{L}$ and $\phi_{Q}^{L}$ : i.e. the loss in expected welfare that follows, in the absence of optimal intervention by the exporting country, from the QR-possibility.

This measure clearly is: $\rho \bar{P}(\bar{U}-\underline{U})$ and is, of course, nothing but the expected loss in period-2 from the possible imposition of the quota, duly discounted.

Now, it is also clear that this measure will lie between the ex-post period-2 loss if the quota is invoked (which loss, duly discounted, is $\rho(U-\underline{U}))$ and the ex-post period-2 loss if the quota is not invoked (which loss is, of course, zero). Thus, one must regard the actual period-2 loss when the quota is invoked as an upper bound on the loss in this model.

It also follows that there is a welfare loss, 
measured as $\rho \bar{P}(\bar{U}-U)$ even if the quota is not actually invoked in period 2 and, (in our 2-period model), the actual equilibrium allocations in each period are identical between the QR-possibility and the no-QR-possibility situations. This follows clearly from the fact that, in period 1 , consumers face the prospect of uncertain prices in period 2, as the QR may or may not be invoked.

Measure II: Alternatively one may measure the loss to the exporting country as the difference between $\phi_{N Q}^{O P T}$ and $\phi_{Q}^{O P T}$, the difference between expected welfare when there is no QR-possibility but the optimal tariff to exploit monopoly power is being exercised and that when the government of the exporting country intervenes with optimal policy to maximize expected welfare when there is a QR-possibility. This alternative measure would be more meaningful ior exporting countries with governmental trade agencies or exporters' associations with ability to regulate their overall export levels, whereas Measure I would be more meaningful for exporting countries with (only) atomistic exporters.

\section{Adjusting for adjustment costs: a putty- clay model}

So far, our analysis was based on the assumption that the choice of optimal production in period 2 was not constrained by the choice of production in period 1. Thus, in Figure 1, the economy could move from $P_{1}$ or $P_{2}$ in period 1 to $P_{3}$ in period 2, along the (long-run) transformation curve $A B$. However, this procedure fails to take into consideration possible adjustment costs: i.e., we were essentially dealing with a putty model.

However, this procedure eliminates an important aspect of the problem raised by market disruption. So, in this section, we modify our model and analysis to allow for adjustment costs. However, to simplify the analysis, we take initially the extreme polar case of a putty-clay model, where the production choice made in period 1 cannot be modified in any way in period 2.

With this modification, the choice variables now are: $X_{i}$, the production of commodity $i$ in periods 1 and $2(i=1,2) ; E_{1}$, the net exports of commodity 1 in period 1 ; and $E_{2}$, the net exports of commodity 1 in period 2 when no quota is imposed. As before, $E$ is the net export of commodity 1 when the quota is imposed. Superscripts refer to periods 1 and 2 .
Clearly then, the expected welfare $\phi$ is now as follows:

$$
\begin{aligned}
\phi= & U^{1}\left[X_{1}-E_{1}, X_{2}+\pi E_{1}\right] \\
& +\rho P\left(E_{1}\right) \underline{U}^{2}\left[X_{1}-E, X_{2}+\pi \bar{E}\right] \\
& +\dot{\rho}\left\{1-P\left(E_{1}\right)\right\} \bar{U}^{2}\left[X_{1}-E_{2}, X_{2}+\pi E_{2}\right] .
\end{aligned}
$$

This is then maximized subject to the implicit transformation function, $F\left(X_{1}, X_{2}\right)=0$, as before. The first-order conditions for an interior maximum then are:

$$
\begin{aligned}
\frac{\partial \phi}{\partial X_{1}}= & U_{1}^{1}+\rho P\left(E_{1}\right) \underline{U}_{1}^{2} \\
& +\rho\left\{1-P\left(E_{1}\right)\right\} \bar{U}_{1}^{2}-\lambda F_{1}=0 \\
\frac{\partial \phi}{\partial X_{2}}= & U_{2}^{1}+\rho P\left(E_{1}\right) \underline{U}_{2}^{2} \\
& +\rho\left\{1-P\left(E_{1}\right)\right\} \bar{U}_{2}^{2}-\lambda F_{2}=0 \\
\frac{\partial \phi}{\partial E_{1}}= & -U_{1}^{1}+\left\{\pi\left(E_{1}\right)+E_{1} \pi^{\prime}\left(E_{1}\right)\right\} U_{2}^{1} \\
& -\rho P^{\prime}\left(E_{1}\right)\left\{U^{2}-U^{2}\right\}=0
\end{aligned}
$$

$\frac{\partial \phi}{\partial E_{2}}=$

$\rho\left[-\bar{U}_{1}^{2}+\left\{\pi\left(E_{2}\right)+E_{2} \pi^{\prime}\left(E_{2}\right)\right\} \bar{U}_{2}^{2}\right]\left\{1-P\left(E_{1}\right)\right\}$

$=0$

$$
\text { where } \begin{aligned}
U_{\mathrm{j}}^{1} & =\frac{\partial U\left[X_{1}-E_{1}, X_{2}+\pi E_{1}\right]}{\partial X_{\mathrm{j}}}, \\
\bar{U}_{\mathrm{j}}^{2} & =\frac{\partial U\left[X_{1}-E_{2}, X_{2}+\pi E_{2}\right]}{\partial X_{\mathrm{j}}}, \\
U_{\mathrm{j}}^{2} & =\frac{\partial U\left[X_{1}-\bar{E}, X_{2}+\pi \bar{E}\right]}{\partial X_{\mathrm{j}}}, \quad \text { and }
\end{aligned}
$$

$\lambda=$ the Lagrangean multiplier associated with the constraint,

$$
F\left(X_{1}, X_{2}\right)=0 .
$$

The interpretation of these first-order conditions is straightforward. Condition (7) states that, given the optimal production levels, the level of exports in period 2 when no quota is imposed must be such as to equate the marginal rate of substitution in consumption to the marginal terms of trade. Condition (6) is identical in form to the one obtained earlier: the optimal exports in period 1 must not equate the marginal rate of substitution in con- 
sumption in that period to the marginal terms of trade, but must instead also allow for the marginal change in expected welfare arising out of the change in probability of a quota being imposed: the latter equals $P^{\prime}\left(E_{1}\right)\left(\bar{U}_{2}-\underline{U}_{2}\right)$ where $\bar{U}_{2}=U\left[X_{1}-E_{2}, X_{2}+\pi E_{2}\right]$ and $\underline{U}_{2}=U\left[X_{1}-E, X_{2}+\pi E\right]$. Thus, condition (6) ensures the optimal choice of exports in period 1 , given the production levels. Conditions (4) and (5) then relate to the optimal choice of production levels and, as we would expect, the introduction of adjustment costs does make a difference. Writing (4) and (5) in the familiar ratio form, we get:

$\frac{F_{1}}{F_{2}}=\frac{U_{1}^{1}+\rho P\left(E_{1}\right) \underline{U}_{1}^{2}+\rho\left\{1-P\left(E_{1}\right)\right\} U_{1}^{2}}{U U_{2}^{1}+\rho P\left(E_{1}\right) \underline{U}_{2}^{2}+\rho\left\{1-P\left(E_{1}\right)\right\} \bar{U}_{2}^{2}}$.

Clearly therefore the marginal rate of transformation in production (in periods 1 and 2, identically, as production in period 1 will carry over into period 2 by assumption), i.e. $F_{1} / F_{2}$, must not equal the marginal rate of substitution in consumption in period 1 , i.e. $U_{1}^{1} / U_{2}^{1}$, (unlike our earlier analysis without adjustment costs in Sections I and II). Rather, $F_{1} / F_{2}$ should equal a term which properly takes into account the fact that production choices once made in period 1 cannot he changed in period 2 to suit the state (i.e. the imposition or absence of a quota) obtaining in period 2. Equation (8) can be readily interpreted as follows.

The LHS is, of course, the marginal rate of transformation in production. The RHS represents the marginal rate of substitution in consumption, if re-interpreted in the following sense. Suppose that the output of commodity 1 , the exportable, is increased by one unit in period 1 (and hence in period 2 as well, by assumption). Given an optimal trade policy, then, the impact of this on welfare can be examined by adding it to consumption in each period. Thus social utility is increased in period 1 by $U_{1}^{1}$ while in period 2 it will increase by $\bar{U}_{1}^{2}$ if no quota is imposed and by $\underline{U}_{1}^{2}$ if the quota is imposed. Thus, the discounted increase in period 2 welfare is given as:

$$
\rho\left[\begin{array}{ll}
U_{1}^{2} & P\left(E_{1}\right)+\tilde{U}_{1}^{2}\left(1-P\left(E_{1}\right)\right)
\end{array}\right] .
$$

Thus, the total expected welfare impact of a unit increase in the production of commodity 1 is:

$$
U_{1}^{1}+\rho\left[\underline{U}_{1}^{2} P\left(E_{1}\right)+\bar{O}_{1}^{2}\left(1-P\left(E_{1}\right)\right)\right]
$$

Similarly, a decrease in the production of commodity 2 by a unit in period 1 (and hence in period 2 as well) reduces expected welfare by:

$$
U_{2}^{1}+\rho\left[U_{2}^{2} P\left(E_{1}\right)+\bar{U}_{2}^{2}\left(1-P\left(E_{1}\right)\right)\right] .
$$

Hence, the ratio of these two expressions, just derived, represents the 'true' marginal rate of substitution, and this indeed is the RHS in Equation (8) to which the marginal rate of transformation in production $-F_{1} / F_{2}$, the LHS in Equation (8) - is to be equated for optimality.

The optimal policy interventions in this modified model with adjustment costs are immediately evident from Equations (6) - (8) and the preceding analysis. Thus, in period 1 , the ratio $U_{1}^{1} / U_{2}^{1}$ is clearly the relative price of commodity 1 (in terms of commodity 2) facing consumers, while $\pi\left(E_{1}\right)$ is the average terms of trade. Thus $U_{1}^{1} / U_{2}^{1}$ differs from $\pi\left(E_{1}\right)$ by

$$
\left[\pi^{\prime} E_{1}-\frac{\rho P^{\prime}\left(E_{1}\right)\left\{\bar{U}^{2}-\underline{U}^{2}\right\}}{U_{2}^{1}}\right]
$$

and this difference constitutes a consumption tax on the importable, commodity 2 . An identical difference between $F_{1} / F_{2}$, the relative price facing producers, and $\pi\left(E_{1}\right)$ would define a production tax on commodity 2 at the same rate, so that a tariff at this rate would constitute the appropriate intervention in the model with no adjustment costs. However, with adjustment costs, Equation (8) defines, for period 1, the appropriate production tax-cumsubsidy which, in general, will diverge from the appropriate consumption tax: so that the optimal mix of policies in the model with adjustment costs will involve a tariff (reflecting both the monopoly power in trade and the QR possibility) plus a production tax-cum-subsidy in period 1.6 In period 2 , in both the models (with and without adjustment costs), an appropriate intervention in the form of a tariff (to exploit monopoly power) would be called for; however, with production fixed at period 1 levels in the adjustment-cost model, a consumption tax-cum-subsidy would equally suffice. Specifically, note that in period 2, with adjustment costs, the price ratio facing consumers would be $\bar{U}_{1}^{2} / \bar{U}_{2}^{2}$ if no quota is imposed, with the average terms of trade at $\pi\left(E_{2}\right)$ and the producers' price ratio (as defined along the putty-transformation frontier) would be $F_{1} / F_{2}$; on the other hand, if the quota is imposed, these values change to $\underline{U}_{1}^{2} / \underline{U}_{2}^{2}, \pi(\bar{E})$ and $F_{1} / F_{2}$ respectively. The consumption taxcum-subsidy and the equivalent tariff (with no 
impact on production decision, already frozen at period 1 levels), are then defined by these divergences, depending on whether the quota obtains or not.

A tabular comparison of the characteristics of the optimal solution, with and without adjustment costs, is presented in Table 2 and should assist the reader.

Note that the above results are quite consistent with the basic propositions of the theory of distortions, as developed in BhagwatiRamaswami (1963), Johnson (1965) and Bhagwati (1971): the first-best, optimal policy intervention for the case with adjustment costs requires a trade policy to adjust for the foreign distortion (represented by the effect of current exports on the period 2 probability of a quota being invoked) and a production tax-cumsubsidy to adjust for the existence of adjustment costs in production. It also follows, from the equivalence propositions, that the combination of the optimal tariff and the optimal production tax-cum-subsidy can be reproduced identically by a tariff set at the 'net' production tax-cum-subsidy required by the optimal solution plus a consumption tax-cum-subsidy. Similarly, while our analysis has been focused on first-best policy intervention, the fundamental results of the theory of distortions and welfare on second-best policies also can be immediately applied to our problem. Thus, if there are zero adjustment costs so that there is only the foreign distortion in period 1 , then clearly a production tax-cumsubsidy will improve (but not maximize) welfare. Similarly, if there are adjustment costs as well, then there will be two distortions and then we would now have applicable here the Bhagwati-Ramaswami-Srinivasan (1969) proposition that no feasible, welfare-improving form of intervention may exist if both of the policy measures that will secure optimal intervention cannot be used simultaneously.

Table A2. Characteristics of optimal solutions in models with and without adjustment costs $\mathrm{s}^{\mathrm{a}}$

\begin{tabular}{lll}
\hline & No adjustment costs & \multicolumn{1}{c}{ Adjustment costs } \\
\hline Period 1 & $\mathrm{DRS}_{1} \neq \mathrm{FRT}_{1}$ & $\mathrm{DRS}_{1} \neq \mathrm{FRT}_{1}$ \\
& $\mathrm{DRS}_{1}=\mathrm{DRT}_{1}$ & $\mathrm{DRS}_{1} \neq \mathrm{DRT}_{1}$ \\
\hline Period 2 & $\mathrm{DRS}_{2}=\mathrm{DRT}_{2}$ & $\mathrm{DRS}_{2}=\mathrm{FRT}_{2}$ \\
& $=\mathrm{FRT}_{2}$ & $\begin{array}{l}\text { (DRT } \\
\text { production is frozen } \\
\text { at period 1 levels) }\end{array}$ \\
\hline
\end{tabular}

Notes: a. DRS, DRT and FRT represent the marginal rates of substitution in consumption, domestic transformation, and foreign transformation respectively. For an earlier use of these abbreviations see Bhagwati, Ramaswami and Srinivasan (1969). Since we are considering an interior maximum, the inequalities do not include corner equilibria, of course. The subscripts refer to the periods, 1 and 2.

\section{NOTES}

1. The full-length $J I E$ paper also extends the analysis to lesser rigidity and to steady state analysis.

2. This method of introducing market disruption presupposes that the QR-level is prespecified but that the probability of its being imposed will be a function of how deeply the market is penetrated in the importing country and therefore how effective the import-competing industry's pressure for protection will be vis-à-vis the importing country's government. The effect of modifying this simplifying assumption so as to allow for varying levels of quota is noted later in this section.

3. Instead of assuming that the fixed quota of $E$ will be imposed with probability $P(E)$, one could assume that a quota of $E$ will be imposed with probability density $P(E, E)$. In other words, the quota level $E$ is variable and the probability of imposition depends both on the level $\bar{E}$ and on the quantum of exports $E$ in the first period. Let $f(\bar{E})$ denote the maximum of $U\left(C_{1}, C_{2}\right)$ subject to $F\left(X_{1}, X_{2}\right)=0$ and $E \leqslant \bar{E}$ where 
$C_{1}=\left(X_{1}-E_{1}\right)$ and $C_{2}=\left(X_{2}+\pi E_{1}\right)$. Then the expected welfare in period 2 , given the export level $E$ in the first period, is $\int f(E) P(E, E) d E$. Let us denote this by $h(E)$. Thus the maximand $\phi$ now becomes

$U\left[X_{1}-E, X_{2}+\pi E\right]+\rho \mathrm{h}(E)$

and condition ( $\left.3^{\prime}\right)$ becomes

$\frac{U_{1}}{U_{2}}=\pi+\pi^{\prime} E+\frac{\rho h^{\prime}(E)}{U_{2}}$.

Now $h^{\prime}(E)$ is the change in expected welfare in period 2 due to an additional unit of export in period 1 and this has to be added to the marginal terms of trade $\pi+\pi^{\prime} E$. Nothing substantive therefore changes. Note however that if we allow for many exporting countries and if the share in the overall quota level granted in period 2 to one exporting country will increase with the export level achieved by that country in period 1 , this would produce an incentive to increase, rather than decrease, the export level in period 1 , ceteris paribus. Hence our analysis based on one exporting country would need to be modified correspondingly.
4. However, we cannot assert that $\phi_{N Q}^{L}>\phi_{Q}^{O P T}$ except in the case of a small country with no influence on the terms of trade; this follows from the fact that $\phi_{N Q}^{L}$ is no longer the first-best policy in the presence of monopoly power in trade, so that $U^{*}$ may well exceed $\bar{O}$ in Table 1.

5. Needless to say, for a country with no monopoly power, it is not meaningful to think of market disruption leading to QRs: if the country is indeed atomistic in foreign markets, its exports surely will not cause market disruption. Our analysis, of course, allows for monopoly power; only Figure 1 illustrates the simple case of a small country.

6. It should be pointed out that atomistic firms in period 1 are assumed to respond to that period's prices only. This assumption can be justified on the ground that they are likely to assume that these prices will carry over into the next period, since there is no other obvious mechanism by which they can anticipate the 'true' period 2 prices.

Acknowledgement: Appendix II is a truncated version of a paper, jointly authored with T. N. Srinivasan, and published in the Journal of International Economics

- (November 1976).

\section{REFERENCES}

Bhagwati, J., and Ramaswami, V. K., 'Domestic distortions, tariffs and the theory of optimum subsidy', Journal of Political Economy (1963).

Bhagwati, J., and Srinivasan, T. N., 'Optimal intervention to achieve non-economic objectives', Review of Economic Studies (1969).

Bhagwati, J., Ramaswami, V. K., and Srinivasan, T. N., 'Domestic distortions, tariffs and the theory of optimum subsidy: some further results', Journal of Political Economy (1969).

Bhagwati, J., "The generalized theory of distortions and welfare', in Bhagwati et al. (ed.), Trade, Balance of Payments and Growth (Amsterdam: North Holland Publishing Co., 1971).
Brecher, R., 'Optimal commercial policy for a minimum-wage economy', Journal of International Economics (May 1974).

Haberler, G., 'Some problems in the pure theory of international trade', Economic Journal (June 1950).

Johnson, H. G., 'Optimal trade intervention in the presence of domestic distortions', in R. E. Caves, $P$. B. Kenen and H. G. Johnson (eds.), Trade, Growth and the Balance of Payments (Amsterdam: North Holland Publishing Co., 1965).

Mayer, W., 'Short-run and long-run equilibrium for a small, open economy', Journal of Political Economy (September/October 1974). 